Aslan, A., Yalçın, A. (2021). "Sağlık Hizmetlerinde Bireysel Hesap Verebilirlik ve Ardılları Arasındaki ilişkilerde Algılanan Örgütsel Destek ve Örgütlerin Sıkılık Durumunun Düzenleyici Rolü: Şehir Hastanesi'nde Bir Araştırma”, Eskişehir Osmangazi Üniversitesi iỉB Dergisi, 16(1), 227 - 251.

Doi: 10.17153/oguiibf.864257

Başvuru: 19.01.2021

Kabul: 11.03.2021

Araştırma Makalesi/Research Article

\title{
Sağlık Hizmetlerinde Bireysel Hesap Verebilirlik ve Ardılları Arasındaki İlişkilerde Algılanan Örgütsel Destek ve Örgütlerin Sıkılık Durumunun Düzenleyici Rolü: Şehir Hastanesi'nde Bir Araştırma $^{1}$
}

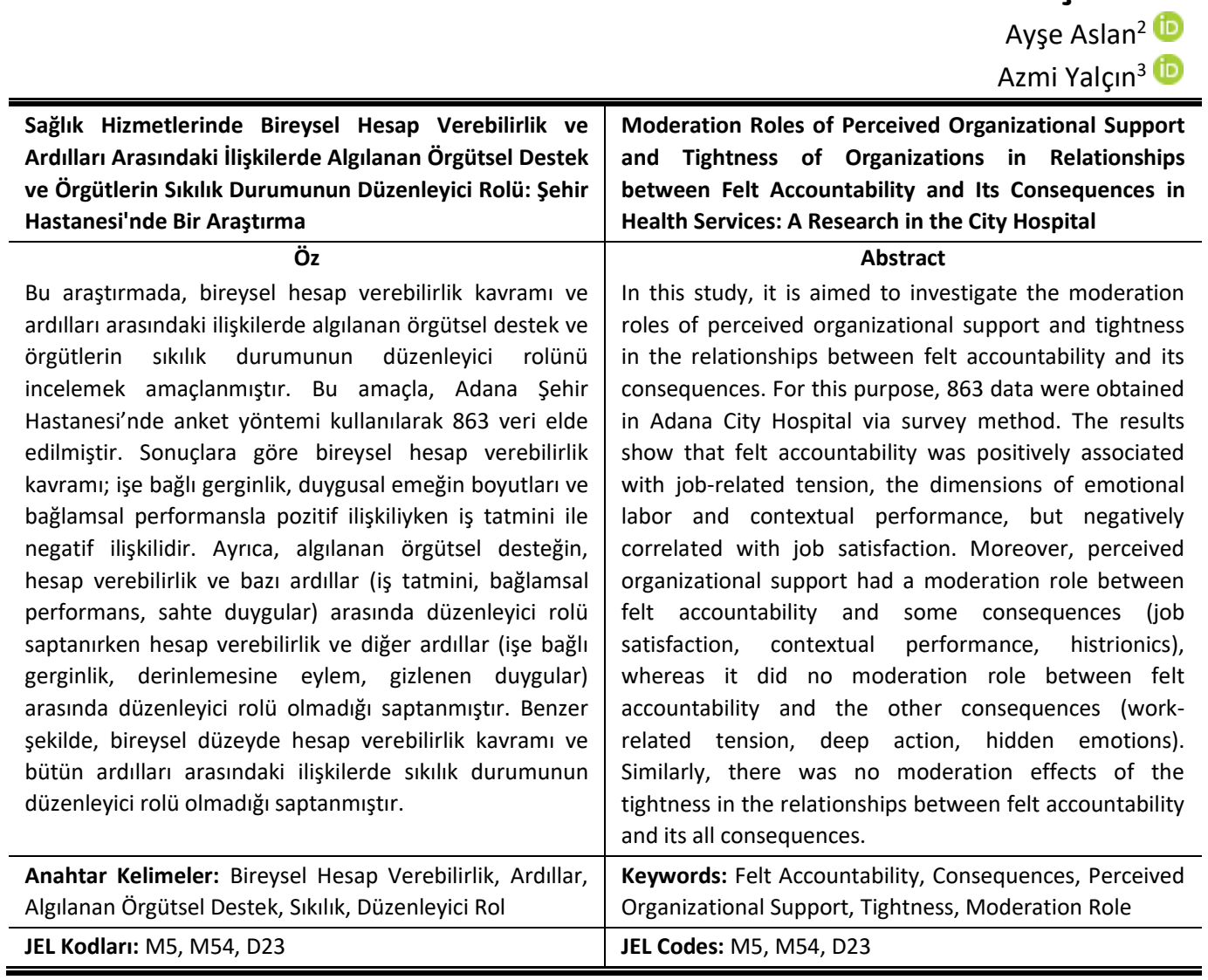

\begin{tabular}{cl}
\hline \hline $\begin{array}{c}\text { Araştırma ve } \\
\text { Yayın Etiği } \\
\text { Beyanı }\end{array}$ & $\begin{array}{c}\text { Bu çalışma (12/03/2018 tarih ve } 38320 \text { sayılı" Etik Onayı Hk." konulu Etik Kurul Onay Belgesi ile) bilimsel } \\
\text { araştırma ve yayın etiği kurallarına uygun olarak hazırlanmıştır. } \\
\text { Yazarların }\end{array}$ \\
$\begin{array}{c}\text { Makaleye Olan } \\
\text { Katkıları }\end{array}$ & \\
Y̧ıkar Beyanı 1'in makaleye katkısı \%50, Yazar 2'nin makaleye katkısı \%50'dir. \\
\hline \hline
\end{tabular}

\footnotetext{
${ }^{1}$ Bu çalışma Çukurova Üniversitesi Sosyal Bilimler Enstitüsü Yönetim ve Organizasyon Anabilim Dalı’nda Prof. Dr. Azmi YALÇıN danışmanlığında Ayşe ASLAN tarafından "Örgütlerde Bireysel Düzeyde Hesap Verebilirliğin Öncülleri ve Ardılları" başlı̆̆ı ile tamamlanarak 14.07.2020 tarihinde savunulan Doktora tezinden türetilmiştir.

Bu çalışma Çukurova Üniversitesi Bilimsel Araştırma Projeleri Komisyonu tarafından desteklenen SDK-2018-10579 numaralı projeden türetilmiştir.

${ }^{2}$ Arş. Gör. Dr., Şırnak Üniversitesi, İktisadi ve İdari Bilimler Fakültesi, İşletme Bölümü, ayseaslan@sirnak.edu.tr

3 Prof. Dr., Çukurova Üniversitesi İiBF, İşletme Bölümü. azmiyalcin@cu.edu.tr
} 


\section{Giriş}

Sağlık hizmetlerinde, eğitimde, cezai ve hukuki adalette, işletmelerde ve özellikle siyasette; kimin, kime karşı, hangi konuda ve hangi temel kurallar çerçevesinde hesap vermesi gerektiğini dikkate alan modern bir terim (Lerner ve Tetlock, 1999: 255) olarak nitelendirilen hesap verebilirlik kavramı bir tarafın faaliyetlerini gerekçelendirdiği ve sorumluluk aldığı prosedürleri ve süreçleri içerdiğinden sağlık hizmetlerinde önemli bir konu haline gelmiştir (Emanuel ve Emanuel, 1996: 229). Sağlık hizmetlerinde hükümet, hastane, yatırımcılar ve sermaye verenler, bireysel hastalar, doktorlar, hemşireler, fizyoterapistler, özel sektör çalışanları, mesleki teşkilatlar, avukatlar ve mahkemeler gibi çeşitli taraflara hesap verilmekte veya bu taraflar kişileri yaptıklarından sorumlu tutmaktadır (Emanuel ve Emanuel, 1996: 230). Türkiye'de Sağlık Bakanlığı sağlık hizmetlerinde örgütsel ve finansman açıdan kamu-özel iş birliği yöntemini kullanmayı tercih etmiştir (Kerman vd., 2012: 14). Kamu-özel iş birliğinde ilgili tarafların farklı davranışsal ve motivasyonel yapılanmalarının olması, beklentilerinin, karar alma süreçlerinin önemli ölçüde farklı olması, hesap verebilirlik anlayışının yapılandırılmasını son derece zorlaştırmakta (Diggs ve Roman, 2012: 293) ve sağlık kuruluşlarını, uyum sağlamaları gereken yeni hesap verebilirlik gereksinimleriyle karşı karşıya (Kromm, 2014: 6) bırakmaktadır.

İlgili alanyazında hesap verebilirlik olgusuna yaşamın birçok alanında ilgi söz konusuyken kavramın birey düzeyinde pek ele alınmadığı, (Lerner ve Tetlock, 1999: 255) örgütlerdeki hesap verebilirlik araştırılırken örgüt tarafından açıkça uygulanan süreç ve prosedürleri içeren resmi hesap verebilirlik mekanizmalarına odaklanıldığı (Hall ve Ferris, 2011: 132) kurumsal yönetişim alanının incelenerek hesap verebilirliğin örgüt düzeyinde incelendiği ve bireysel düzeyde incelenen; bireysel hesap verebilirlik olarak belirtilen psikolojik mekanizmaların dikkate alınmadığı (Hall, 2005: 1) saptanmıştır.

Örgütsel sistemlerde veya insan kaynakları sistemlerinde hesap verebilirlik koşullarının çalışan davranışını nasıl etkilediğini sorgulamak mantıklı göründüğünden (Frink ve Ferris, 1998: 1260) bu araştırmada bireysel düzeyde hesap verebilirliğin çalışanların çeşitli tutum ve davranışları üzerindeki etkileri ortaya konularak, bireysel hesap verebilirlik ve ardılları arasındaki ilişkilerde bazı değişkenlerin düzenleyici rolü incelenecektir. Bu çerçevede alanyazında bireysel hesap verebilirlik ve ardılları incelenirken bağımlı değişkenlerin, duygusal durumlar, davranışlar, bilişsellik ve kararlar olmak üzere 4 gruba ayrıldığı (Hall vd., 2017: 212) görülmektedir. Araştırmamızda bu sınıflandırma dikkate alınarak ardıl değişkenler kapsamında duygusal durum olarak iş tatmini ve işe bağlı gerginlik; davranışlar olarak bağlamsal performans, bilişsellik olarak duygusal emek ve boyutları ele alınmıştır. Ayrıca, bireysel hesap verebilirlik ve ardılları arasındaki ilişkilerde düzenleyici değişkenlerin; odaklanılan aktörün özellikleri, izleyicinin özellikleri, görevin nitelikleri, bağlamsal koşullar, duygusal değiş̧enler ve kültürel değişkenler olmak üzere 6 gruba ayrıldığı (Hall vd., 2017: 211) göze çarpmaktadır. Ancak ilgili alanyazında bireysel düzeyde hesap verebilirlik ve ardılları arasındaki ilişkilerde düzenleyici değişken etkisi ile ilgilenen az sayıda çalışma olduğu (Hall, 2005: 32) tespit edilmiştir. Incelenen düzenleyici değişkenlerden bazıları ise iş belirsizliği (Fandt ve Ferris, 1990; Ferris vd., 1997), iş özerkliği (Hall vd., 2006), bağlamsal faktörler (Tetlock vd., 2013), kötü eğilimli denetim (Breaux vd., 2008), kişilik özellikleri (Yarnold vd., 1988), algılanan örgütsel destek (Hall, 2005; Wikhamn ve Hall, 2014), algılanan kontrol (Hall, 2005), kişi-çevre uyumu (Lanivich vd., 2010) gibi kavramlardır. Bu noktada söz konusu incelenen değişkenler arasında kültürel bir değişkenin incelenmediği saptanmıştır. Buradan hareketle, örgüt 
kültüründe yeni bir boyut olarak değerlendirilen sıkılık-esneklik kavramının alanyazında saptanan ilgili boşluğu dolduracağını ve algılanan örgütsel destek kavramının da farklı bir kültür olarak Türkiye bağlamında incelenecek olması gerekçesiyle bu araştırmanın alanyazına katkı sağlayacağını düşünmekteyiz.

\section{Kavramsal ve Kuramsal Çerçeve}

\subsection{Bireysel Düzeyde Hesap Verebilirlik}

Bireysel düzeyde hesap verebilirlik, dışsal toplumsal kısıtlamaların nasıl içselleştirildiğini ve davranışı nasıl etkilediğini anlamak için geliştirilmiş yeni bir psikolojik mekanizmadır (Gelfand vd., 2006: 1227). Bireysel düzeyde hesap verebilirlik, "bir kişinin kararlarının ya da eylemlerinin, önemli izleyiciler veya kişinin kendisi tarafından değerlendirilmeye tabi tutulacağına dair örtük veya açık bir beklenti ile beklenen bu değerlendirmelere dayanan potansiyel ödüller veya yaptırımlar alacağına ilişkin inançtır" (Hall, 2005: 21). Bireysel düzeyde hesap verebilirlik kuramı, iki farklı yaklaşım temelinde incelenmektedir. Birincisinde, bireyin bilişsel süreçleri, tepkileri ve davranışlarıyla ilgilenilen bireyin hesap verebilirliğine odaklanılmaktadır (Brunhart, 2013: 32). Bu yaklaşıma Tetlock'un önerdiği (1983a; 1983b; 1985a; 1985b; 1992) "sosyal durumsallık modeli" ve Schlenker'in belirttiği "üçlü sorumluluk modeli" ve "hesap verebilirlik piramidi" (Schlenker ve Weigold, 1989; Schlenker vd., 1994: 635; Schlenker vd., 2001: 17; Schlenker vd., 2009: 333) katkı sağlamıştır. İkincisinde ise örgütlerdeki bireysel hesap verebilirlik üzerine odaklanılmaktadır (Brunhart, 2013: 32). Bu araştırma akışında Ferris vd., (1995), Ferris vd. (1997); Frink ve Ferris (1998, 1999); Frink ve Klimoski, (1998); Hall vd., (2003); Hall (2005) gibi araştırmacılar katkıda bulunmuştur.

Cumming ve Anton (1990) ve Schlenker ve arkadaşları (1994) hesap verebilirliğin sorumluluktan farklı olduğunu belirtmektedir. Örgütlerde bireysel düzeyde hesap verebilirlik kavramına katkıda bulunan çalışmalardan, Tetlock (1983a, 1983b, 1985a, 1985b, 1992), Frink ve Ferris (1998, 1999), Frink ve Klimoski (1998), Quinn ve Schlenker (2002) çalışmalarını ağırlıklı olmak üzere fenomenolojik bakış açısı ile yani ruhsal durumu göz önünde bulundurarak yürütmüşlerdir. Cummings ve Anton (1990), Fandt ve Ferris (1990), Mitchell (1993), Ferris ve arkadaşları (1997), Hochwarter ve arkadaşları (2005) ise çalışmalarında işlerin durumu ile ilgili bakış açısını kullanmışlardır. Hall ve arkadaşları (2003), Hall (2005), Hall ve arkadaşları (2006) ise hem fenomolojik bakış açısını ruhsal durumu, hem de işlerin durumunu objektif bakış açısını kullanmışlardır (Brunhart, 2013: 58).

Bireysel düzeyde hesap verebilirlik bir izleyicinin, bir aktöre yüklediği sorumlulukların aksine; aktörün hesap verebilirliğine ilişkin algılarına dayanır (Frink ve Klimoski, 1998; Hall, Frink ve Buckley, 2017: 205). Bu bağlamda, bireysel hesap verebilirlik, bir bireyin birisi tarafından değerlendirildiğine ve bireyin kararları veya eylemleri için sorumlu olduğuna/hesap vereceğine dair algılanan ihtimaldir (Frink ve Ferris, 1998: 1260). Bireysel düzeyde hesap verebilirlik, genellikle basit bir şekilde hesap verebilirlik olarak adlandırılmaktadır ve bir bireyin kendi hesap verebilirliğine ilişkin bireysel algılarıdır (Hall vd., 2017: 205).

Örgütlerde ve bireysel hesap verebilirlik kavramının vekalet teorisi (Jensen ve Meckling, 1976), temsil teorisi (Donaldson ve Davis, 1991), rol teorisi (Katz ve Kahn, 1978), kontrol teorisi (Ouchi, 1977), sosyal kolaylaştırma teorisi (Zajonc, 1965) ve değerlendirilme endişesi teorisine (Cottrell, 1972) dayandırıldığı ve bu kuramlara ilişkin varsayımlardan ve beklentilerden yola çıktığı veya bu kuramlarla ilişkili olduğu belirtilmektedir (Hall, 2005: 12; Schillemans ve Busuioc, 2015: 192; Keay, 2017: 1296). 
Bu araştırmada öncelikle Cumming ve Anton (1990) ve Schlenker ve arkadaşlarının (1994) çalışmalarıyla benzer şekilde, hesap verebilirliğin sorumluluktan farklı olduğu düşüncesi dikkate alınmaktadır. Ayrıca, mevcut çalışmada Tetlock (1983a, 1983b, 1985a, 1985b, 1992) tarafından önerilen bireysel hesap verebilirliğin öznel algısının incelendiği hesap verebilirliğe ilişkin fenomenolojik bakış açısı benimsenmiş ve Frink ve Klimoski (1998) tarafından savunulan hesap verebilirliğe yönelik rol teorisi yaklaşımı benimsenmiştir. Araştırmamızda ayrıca, Hall (2005: 21) tarafından daha önceki araştırmacıların çalışmalarına dayandırarak önerdiği tanımlama dikkate alınmaktadır. Buna göre bireysel hesap verebilirlik, "bir kişinin kararlarının ya da eylemlerinin, önemli izleyiciler veya kişinin kendisi tarafından değerlendirilmeye tabi tutulacağına dair örtük veya açık bir beklenti ile beklenen bu değerlendirmelere dayanan potansiyel ödüller veya yaptırımlar alacağına ilişkin inançtır" (Hall, 2005: 21).

\subsection{Bireysel Düzeyde Verebilirliğin Ardılları ve İlgili Literatür}

Hesap verebilirliğin bağımlı değişkenleri olarak incelenecek kavramları Hall ve arkadaşları (2017: 212) duygusal durumlar, davranışlar, bilişsellik ve kararlar olmak üzere 4 kategoriye ayırmıştır. Araştırmamızda ardıllar, Hall ve arkadaşlarının (2017: 212) sınıflandırması dikkate alınmıştır. Duygusal durum olarak iş tatmini ve işe bağlı gerginlik; davranışlar olarak bağlamsal performans, bilişsellik olarak duygusal emek ve boyutları incelenmiştir.

\subsection{1. İş Tatmini ve Bireysel Düzeyde Hesap Verebilirlik ile ilişkisi}

Bir kişinin "gerçekten işimden memnunum" demesine neden olan psikolojik, fizyolojik ve çevresel koşulların bir birleşimi (Ali, 2008: 241) olan iş tatmini, örgütlerde bireysel düzeyde hissedilen hesap verebilirlik tartışmasında önemli sonuçlardan biridir ve hesap verebilirliğin artması bireyler için bir stres yaratırsa, o bireylerin iş tatmini üzerinde de bir etki beklenmektedir (Breaux vd., 2008: 114). Literatürde bazı çalışmalarda hesap verebilirlik ve iş tatmini arasında pozitif ilişki (Specht, 1996; Thoms vd., 2002, Sorensen vd., 2009; Breaux vd., 2008; Breaux vd., 2009; Laird vd., 2009; Laird vd., 2015; Royle, 2017) bazılarında negatif ilişki (Hall, vd., 2006; Lanivich, vd., 2010) olduğu tespit edilmiştir.

\subsection{2. İşe Bağlı Gerginlik ve Bireysel Düzeyde Hesap Verebilirlik ile İlişkisi}

Bireyin iş rolleri ve olumsuz rol sonuçlarından kaynaklanan duygusal (Lusch ve Serpkenci, 1990: 88) ve psikolojik bir durum olarak ele alınan ve bireyin çevresindeki stresörlere karşı verdiği psikolojik tepkiler olarak ifade edilen (Van Dyne vd., 2002: 59) işe bağlı gerginliğin ortaya çıkmasında çevresel, örgütsel etmenler ve kişisel özellikler (Beehr ve Newman, 1978: 671) etkilidir. Hesap verebilirliğin genellikle, çalışan davranışları üzerinde olumlu bir etkisi olduğu kabul edilse de (Goodman vd., 2011: 75) iş gerginliği gibi gerilme reaksiyonlarını da yükseltebilmektedir (Hochwarter vd., 2007: 227). Yapılan araştırmalar (Hall vd., 2003; Hochwarter vd., 2007), hesap verebilirlikteki artışların yüksek düzeyde iş gerginliğine yol açacağını ileri sürmektedir (Breaux vd., 2008: 114). Çalışmalarda (Ferris vd.,1995; Hall vd.,2003; Hochwarter vd., 2005; Hall vd., 2006; Hochwarter vd., 2007; Breaux vd., 2008; Laird vd., 2009; Zellars vd., 2011) hesap verebilirlik ve işe bağlı gerginlik arasında pozitif ilişki tespit edilmiştir.

\subsubsection{Duygusal Emek ve Bireysel Düzeyde Hesap Verebilirlik ile İlişkisi}

Çalışanlar, örgüt temelli beklentileri karşılamak amacıyla duygusal gösterimlerini, örgütteki rollerine özgü düzenlemeye çalıştıklarında (Brotheridge ve Lee, 2003: 365) yani, deneyimleyebilecekleri gerçek duygulardan bağımsız olarak, örgütsel olarak uygun olan duygular sergilediklerinde duygusal emek (Hall vd., 2003: 44) söz konusu olmaktadır. 
İlgili alanyazında duygusal emeğin çok boyutlu bir yapıya sahip olduğu (Brotheridge ve Lee, 2003: 366; Çelik \& Topsakal, 2016: 204) görülmektedir. Duygusal emek kavramının boyutlarından derinlemesine eylem boyutu, "uygun duygu ve ifadeleri gerçek anlamda gösterebilme çabaları" olarak tanımlanırken, gizlenen duygular boyutu, "belli bir durumda gösterilmesi kabul edilemez veya uygun görülmeyen duyguların saklanması" olarak tanımlanmakta ve duygusal emeğin bir diğer boyutu olarak incelenen sahte duygular boyutu ise, "çalışanın, gerçekten hissetmese bile belli duyguları göstermeye çalışması" (Dursun vd., 2014: 14) olarak tanımlanmaktadır.

Davranışlarından dolayı sorumlu tutulduğunu veya davranışlarına ilişkin hesap vereceklerini hisseden bireyler, performanslarının değerlendirileceğini düşünmekte, onları değerlendiren önemli izleyicilerden olumlu bir değerlendirme almak için "doğru" duyguları göstermeleri gerektiğine inanmakta ve davranışlarını ilgili izleyici tarafından kabul edileceğine inandıkları şekilde değiştirmektedirler (Hall vd., 2003: 44). Hall ve arkadaşları (2003), hesap verebilirlik ve duygusal emek arasında pozitif bir ilişki tespit etmiştir.

\subsubsection{Bağlamsal Performans ve Bireysel Düzeyde Hesap Verebilirlik ile iliş̧kisi}

Bağlamsal performans, resmi olarak işin bir parçası olmayan göreve ilişkin faaliyetleri yürütmek için gönüllü olmayı, örgütteki diğer kişilere yardım etmeyi ve onlarla iş birliği içinde olmayı (Borman ve Motowidlo, 1997: 100), iyi iş ilişkilerini sürdürmeyi (Van Scotter ve Motowidlo, 1996: 526) veya meslektaşlarını işle ilgili sorunlar hakkında uyarmayı, ekstra çaba göstermeyi, örgüt kurallarına ve prosedürlerine uymayı içermektedir (Sonnentag vd., 2008: 429). Kişinin kararları ve eylemleri için sorumlu tutulma deneyiminin, iş performansını etkilediği ve arttırdığı kabul edilmektedir (Antonioni, 1994: 349). Yüksek düzeyde hesap verebilirlik hisseden çalışanların, potansiyel bir değerlendirme beklediğinden amirlerinden en olumlu görüşleri almak için önemli adımlar atacakları bu doğrultuda örgütsel vatandaşlık davranışı (Hall, vd., 2003: 42) ve örgüte yaptıkları katkılara dikkat çekmek için extra-rol davranışı sergileyebilecekleri (Hall ve Ferris, 2011: 133) ya da ekstra çalışma yapmak yerine yalnızca kendilerinden istenen, gerekli olan işleri yapabileceğini (Mitchell vd., 1998: 511) belirtmek de fayda vardır. Chen ve arkadaşları (2016) bireysel düzeyde hesap verebilirlik ve bağlamsal performans arasında pozitif bir ilişki saptamıştır.

\subsection{Bireysel Düzeyde Hesap Verebilirliğin Düzenleyici Değişkenleri}

Bireysel düzeyde hesap verebilirlik ve ardılları arasındaki ilişkide düzenleyici değişkenler "odaklanılan aktörün özellikleri, izleyicinin özellikleri, görevin nitelikleri, bağlamsal koşullar, duygusal değişkenler, kültürel değişkenler" olmak üzere 6 gruba ayrılmıştır (Hall vd., 2017: 211). Algılanan örgütsel destek ve örgütlerin sıkılık durumu düzenleyici değiş̧kenlerimizdir.

\subsection{1. Örgüt Kültüründe Yeni Boyut Sıkılık-Esneklik}

Sıkılık-esneklik kavramını, Gelfand ve arkadaşları (2006: 1226) "belirli bir toplumdaki, toplumsal normların gücü ve yaptırım düzeyi” olarak tanımlamaktadır. Sıkı bir örgüt kültürüne sahip örgütlerde, daha fazla düzen, uyum ve istikrara vurgu yapılmakta, merkeziyetçi ve biçimsel bir yapının olduğu (Üstün ve Kılıç, 2017: 965), üst düzey hiyerarşinin hakim olduğu, güç ve bilgi dağıtımında dikey yönlü bir iletişimin ön planda olduğu (Şen ve Basım, 2018a: 324) ancak örgütlerin değişime karşı kapalı ve tepkili olması beklenmektedir ve bu örgütlerde kısıtlama, kontrol ve baskının yüksek oranlarda görüldüğü (Wasti ve Fiş, 2010: 9), çalışan performansını değerlendirmek için gelişmiş performans izleme ve değerlendirme sistemleri 
kullanıldığı, ve örgütsel hedeflere yeterince katkıda bulunmayan çalışanlar her zaman cezalandırıldığı (Şen vd., 2019: 66) belirtilmektedir.

Normların ve kuralların, davranış üzerindeki etkisini sorgulayan yeni bir kültürel boyut olan (Şen vd., 2019: 71) sıkılık-esneklik kavramı örgüt kültüründe yeni bir boyut olarak önemli bir bağlamsal faktördür ve belirli becerileri geliştirmek veya azaltmak ve bireylerin algısını etkilemek için etkili bir ortam yaratmaktadır (Altuncu, 2014: 40). Bu nedenle, sıkılık-esneklik ile "birey davranışlarının sosyal normlardan ve yaptırımlardan ne kadar etkilendiği" (Kılıç, vd., 2020: 2880) araştırılabilmektedir. Ilgili literatürde bireysel düzeyde hesap verebilirlik ve ardılları arasındaki ilişkilerde örgütlerin sıkılık durumunun düzenleyici değişken rolünü inceleyen çalışmaya rastlanmamıştır. Bununla birlikte, bireylerin çalıştıkları örgüt, çalışma ortamından etkilenerek, farklı davranış/tutumlar gösterebildiklerini (Şen ve Basım, 2018a: 332) kanıtlamak amacıyla yapılan bazı çalışmalarda sıkılık-esnekliğin durumunun, düzenleyici rolü olduğu (Şen ve Basım, 2018a; Şen ve Basım, 2018b; Liu vd., 2018; Tang vd., 2019) bazı çalışmalarda ise düzenleyici rolü olmadığı (Altuncu, 2014; Lönnqvist, 2015; Şen vd., 2019) görülmüştür. Örgütlerin sıkılık durumunun, bireysel düzeyde hesap verebilirliğin zararlı etkilerini azaltacağını, olumlu etkilerini de arttıracağını düşünerek oluşturduğumuz hipotezlerimiz şunlardır:

H1. Bireysel hesap verebilirlik ve iş tatmini arasındaki ilişkide örgütlerin sıkılık durumunun düzenleyici değişken etkisi vardır.

H2. Bireysel hesap verebilirlik ve işe bağlı gerginlik/kaygı arasındaki ilişkide örgütlerin sıkılık durumunun düzenleyici değişken etkisi vardır.

H3. Bireysel hesap verebilirlik ve duygusal emek arasındaki ilişkide örgütlerin sıkılık durumunun düzenleyici değişken etkisi vardır.

H3a. Bireysel hesap verebilirlik ve derinlemesine eylem arasındaki örgütlerin sıkılık durumunun düzenleyici değişken etkisi vardır.

H3b. Bireysel hesap verebilirlik ve sahte duygular arasındaki ilişkide örgütlerin sıkılık durumunun düzenleyici değişken etkisi vardır.

H3c. Bireysel hesap verebilirlik ve gizlenen duygular arasındaki ilişkide örgütlerin sıkılık durumunun düzenleyici değişken etkisi vardır.

H4. Bireysel hesap verebilirlik ve bağlamsal performans arasındaki ilişkide örgütlerin sıkılık durumunun düzenleyici değişken etkisi vardır.

\subsubsection{Algılanan Örgütsel Destek}

Algılanan örgütsel destek; “örgütlerin, çalışanlarının katkılarına ne ölçüde değer verdiğine ve çalışanlarının refahı ile ne kadar ilgilendiğine ilişkin" çalışanların oluşturduğu genel bir inanç (Eisenberger vd., 1997: 812), algı (Kurtessis vd., 2017: 1854) veya fikirlerdir (Dawley vd., 2010: 239). Algılanan örgütsel desteğin, örgütsel ilişkileri yönetmede önemli olduğu (Cheng ve OYang, 2018: 80), çalışanlar tarafından bireysel düzeyde hissedilen hesap verebilirlik ile iş tatminleri veya işe bağlı gerginlik arasındaki ilişkide (Hall, 2005; Wikhamn ve Hall, 2014) düzenleyici değişken etkisi olabileceği önerilmektedir.

Alanyazında sadece Wikhamn ve Hall (2014) bireysel düzeyde hesap verebilirlik ve iş tatmini arasındaki ilişkide algılanan örgütsel desteğin düzenleyici rolünü incelemiş ve düzenleyici rolü olduğunu saptamıştır. Ayrıca literatürde bazı değişkenler arasındaki ilişkide algılanan örgütsel desteğin düzenleyici etkisi olduğunu saptayan çalışmalar (Lynch vd., 1999; 
Stamper ve Johlke, 2003; Erdogan vd., 2004; Witt ve Carlson, 2006; Erdogan ve Enders, 2007; Nixon vd., 2011; Conway ve Coyle-Shapiro, 2012; Hur vd., 2015; Palmer vd., 2017; Sökmen vd., 2017; Chung, 2017; Cheng ve O-Yang, 2018; Uzunbacak vd., 2018; Işık, 2019; Acaray, 2019; Koçak, 2020) olduğu bazı çalışmalarda (Gopalkrishnan, 2011; Fettahlıoğlu ve Koca,2015) ise düzenleyici rolü olmadığı görülmüştür. Butts ve arkadaşları (2009) ise bazı değişkenler arasında algılanan örgütsel desteğin düzenleyici rolü olduğunu, bazı değişkenler arasında ise düzenleyici rolü olmadığını bulgulamıştır. Buna göre araştırma hipotezlerimiz şunlardır:

H5. Bireysel hesap verebilirlik ve iş tatmini arasındaki ilişkide algılanan örgütsel desteğin düzenleyici değişken etkisi vardır.

H6. Bireysel hesap verebilirlik ve işe bağlı gerginlik/kaygı arasındaki ilişkide algılanan örgütsel desteğin düzenleyici değişken etkisi vardır.

H7. Bireysel hesap verebilirlik ve duygusal emek arasındaki ilişkide algılanan örgütsel desteğin düzenleyici değişken etkisi vardır.

H7a. Bireysel hesap verebilirlik ve derinlemesine eylem arasındaki ilişkide algılanan örgütsel desteğin düzenleyici değişken etkisi vardır.

H7b. Bireysel hesap verebilirlik ve sahte duygular arasındaki ilişkide algılanan örgütsel desteğin düzenleyici değişken etkisi vardır.

H7c. Bireysel hesap verebilirlik ve gizlenen duygular arasındaki ilişkide algılanan örgütsel desteğin düzenleyici değişken etkisi vardır.

H8. Bireysel hesap verebilirlik ve bağlamsal performans arasındaki ilişkide algılanan örgütsel desteğin düzenleyici değişken etkisi vardır.

\section{Metodoloji}

\subsection{Araştırma Modeli}

Araştırmamızın kavramsal modeli Şekil 1'de gösterilmektedir.

\section{Şekil 1: Araştırma Modeli}

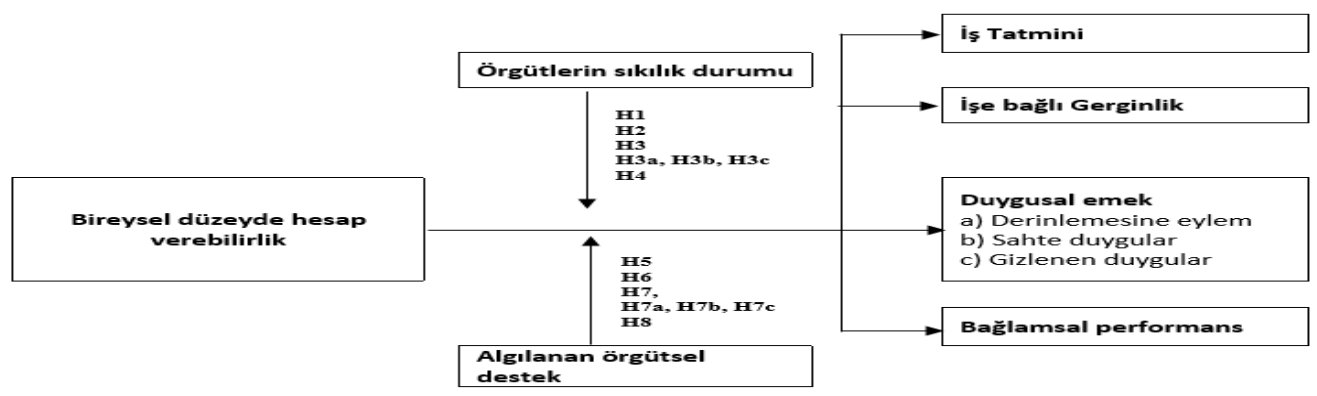

Araştırma modeli kapsamında bireysel düzeyde hesap verebilirlik kavramı bağımsız değişken olarak ele alınırken, iş tatmini, işe bağlı gerginlik, bağlamsal performans, duygusal emek ve boyutları ise bağımlı değişkenlerimizi oluşturmaktadır. Ayrıca, örgütlerin sıkılık durumu ve algılanan örgütsel destek düzenleyici değişken olarak değerlendirilmektedir.

\subsection{Araştırma Evreni ve Örneklemi}

Araştırmanın evreni Adana Şehir Eğitim ve Araştırma Hastanesi çalışanlarından oluşmaktadır. Zaman ve bütçe gibi kısıtlar nedeniyle evreninin tamamına ulaşılamadığından kolayda ve kartopu örnekleme metoduyla 911 anket toplanmış, 48 anket ise eksik bilgi içerdiğinden analizlere dahil edilmemiş ve 863 çalışana ait veri analizlerde kullanılmıştır. 


\subsection{Veri Toplama Yöntemi ve Araçları}

Araştırmaya katılanlar, çoğunlukla görev açısından yoğun olan bir ortamda çalışan bireyler olduğundan araştırmaya ilişkin veri anket yöntemiyle, 5'li Likert ölçek kullanılarak (1: Kesinlikle Katılmıyorum ile 5: Kesinlikle katılıyorum arasında) kesitsel zaman aralığında (03.05.2018 ile 31.08.2018 tarihleri arasında) toplanmıştır. Araştırmada kullanılan ölçüm araçları Tablo 1 'dedir.

Tablo 1: Araştırmada Kullanılan Ölçüm Araçları

\begin{tabular}{|c|c|c|}
\hline Ölçüm Araçları & Ölçüm Aracını Geliştirenler ve Türkçe'ye Uyarlayanlar & Madde ve Boyutlar \\
\hline $\begin{array}{l}\text { Bireysel Düzeyde } \\
\text { Hesap Verebilirlik }\end{array}$ & $\begin{array}{l}\text { Hochwarter ve arkadaşları (2003) tarafından geliştirilmiştir. Bu çalışmada } \\
\text { Türkçe'ye çevrilmiştir. }\end{array}$ & 8 madde; tek boyut \\
\hline İş Tatmini & $\begin{array}{l}\text { Brayfield ve Rothe (1951) } 18^{\prime} \text { lik madde; Judge ve arkadaşlarının (1998) kısalttığı } \\
\text { versiyon bu çalışmada Türkçe'ye çevrilmisstir. }\end{array}$ & 5 madde; tek boyut \\
\hline İşe Bağlı Gerginlik & $\begin{array}{l}\text { House ve Rizzo (1972) tarafından geliştirilen; Hall (2005) uyarlanan versiyon bu } \\
\text { çalışmada Türkçe'ye çevrilmiştir. }\end{array}$ & 6 madde; tek boyut \\
\hline $\begin{array}{l}\text { Örgütlerin Sıkılık } \\
\text { Durumu }\end{array}$ & $\begin{array}{l}\text { Khandwalla (1976) tarafından geliştirilen, Wasti ve Fiş (2010) tarafından } \\
\text { Türkçe'ye uyarlanan ölçüm aracı kullanılmıştır. }\end{array}$ & 5 madde; tek boyut \\
\hline Duygusal Emek & $\begin{array}{l}\text { Brotheridge ve Lee (2003) tarafından geliştirilen, Bazı araştırmacılar tarafından } \\
\text { revize edilen (Lee ve Brotheridge, 2006), Revize edilen versiyonu, Lee ve } \\
\text { Brotheridge, (2011) tarafından kullanıldı̆ı görülmüş̧ür. Lee ve Brotheridge } \\
2011 \text { kullandığı versiyonu Dursun ve arkadaşları (2014) Türkçe'ye uyarlamıştır. } \\
\text { Türkçe'ye uyarlanan versiyon kullanılıışır. }\end{array}$ & $\begin{array}{l}9 \text { madde; } 3 \text { boyut } \\
\text { Derinlemesine eylem ( } 3 \\
\text { madde) Sahte duygular } \\
\text { ( } 3 \text { madde) } \\
\text { Gizlenen duygular ( } 3 \\
\text { madde) }\end{array}$ \\
\hline $\begin{array}{l}\text { Bağlamsal } \\
\text { performans }\end{array}$ & $\begin{array}{l}\text { Borman ve Motowidlo (1993- 1997) tarafindan geliştirilen; Karakurum (2005) } \\
\text { tezindeki Türkçe versiyonu kullanılmıştır. }\end{array}$ & 5 madde; tek boyut \\
\hline $\begin{array}{l}\text { Algılanan Örgütsel } \\
\text { Destek }\end{array}$ & $\begin{array}{l}\text { Eisenberger ve arkadaşları (1986) tarafından geliştirilen, Armstrong-Stassen ve } \\
\text { Ursel (2009) tarafından kısaltılan versiyonun; Turunç ve Çelik (2010) tarafından } \\
\text { uyarlanan Türkçe versiyonu kullanılmışırı. }\end{array}$ & 10 madde; tek boyut \\
\hline
\end{tabular}

\subsection{Katılımcı Profili}

Uygulamaya katılan 863 çalışanın \%60'ının kadın, \%40'ının erkek, \%66,4'ünün evli, \%33,6'nın bekâr olduğu görülmektedir. Örneklemdeki bireylerin, \%7,2'si memur, \%13,4'ü hemşire, \%20,5'i doktor, \%3,5'i ebe, olarak görev yaparken toplamda \%44,6'sı ise devlet tarafından istihdam edilmektedir. \%55,4'ü ise özel firma tarafından istihdam edilmiş personellerden oluşmaktadır. Örnekleme katılanların yaş ortalaması $34.00 \pm 7.09$ iken yaş

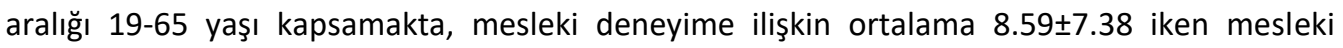
deneyim aralığı 1 ile 41 yıl arasındadır.

\subsection{Veri Analizi ve Bulgular}

Araştırmada normal dağılıma uygunluk, güvenilirlik, korelasyon, keşfedici faktör analizi, çoklu bağlantıya yönelik analizler için SPSS 18.00 programı; doğrulayıcı faktör analizi ve hipotez testleri için AMOS 23.00 programı kullanılmıştır. Değişkenler arasındaki parametre tahmininde yapısal eşitlik modellemesinde en çok (Hair vd., 2010: 636) ve en yaygın kullanılan (Chou ve Bentler, 1995: 38) en yüksek olabilirlik kestirim yöntemi kullanılmıştır.

\subsubsection{Analiz Öncesi Yapılan Testler, Ölçeklere iliş̧kin Güvenilirlik, Faktör Analizleri}

Normal dağılıma uygunluk, testlerle incelenmek istenirse, sıklıkla kullanılan yöntemler arasında Kolmogorov-Smirnov (K-S), Shapiro-Wilk (Hair vd., 2010: 72) testleri kullanılmaktadır. Bu gerekçeyle hipotezleri test etmeden önce değişkenlerin dağılım biçimlerini ortaya çıkarmak için yani tek değişkenli normalliği incelemek için çarpıklık ve basıklık değerlerine ve Kolmogorov-Smirnov (K-S), Shapiro-Wilk (Hair vd., 2010: 71-72) testlerine bakılmıştır. 
Bulgulara göre veri normal dağılımdan sapma gösterdiğinden Tabachnick ve Fidell'in (2013: 89) veri dönüştürme yöntemleri uygulanmıştır. Ölçeklerin güvenilirlik, keşfedici ve doğrulayıcı faktör analizi ve yapı geçerliliğine (AVE ve CR) ilişkin değerler Tablo 2'dedir.

Tablo 2: Ölçüm Araçlarının Güvenilirlik, Faktör ve Yapı Geçerliliği Analizleri

\begin{tabular}{|c|c|c|c|c|c|c|c|c|c|}
\hline Değişken & Boyut & Madde & KF & DF & Açık.var & $\begin{array}{c}\text { KMO; } \chi^{2} \\
\text { Serbestlik } \\
\text { derecesi; } p\end{array}$ & $\begin{array}{c}\text { Cronbach } \\
\text { Alpha }\end{array}$ & AVE & CR \\
\hline \multirow{8}{*}{$\begin{array}{l}\text { Bireysel } \\
\text { düzeyde } \\
\text { hesap } \\
\text { verebilirlik }\end{array}$} & \multirow{8}{*}{ Tek boyut } & BDHV2 & .845 & .83 & \multirow{8}{*}{$\% 62.688$} & \multirow{8}{*}{$\begin{array}{l}\text { KMO }=0.899 \\
\chi^{2}=4283.998 \\
\text { serbestlik } \\
\text { derecesi }=28 \\
p=0.000\end{array}$} & \multirow{8}{*}{.914} & \multirow{8}{*}{.624} & \multirow{8}{*}{.930} \\
\hline & & BDHV1 & .827 & .83 & & & & & \\
\hline & & BDHV3 & .827 & .79 & & & & & \\
\hline & & BDHV7 & .801 & .76 & & & & & \\
\hline & & BDHV4 & .801 & .76 & & & & & \\
\hline & & BDHV5 & .759 & .68 & & & & & \\
\hline & & BDHV8 & .734 & .64 & & & & & \\
\hline & & BDHV6 & .730 & .62 & & & & & \\
\hline \multirow{5}{*}{ İş tatmini } & \multirow{5}{*}{ Tek boyut } & IT2 & .896 & .93 & \multirow{5}{*}{$\% 71.618$} & \multirow{5}{*}{$\begin{array}{l}\text { KMO }=0.850 \\
\chi^{2}=2760.079 \\
\text { serbestlik } \\
\text { derecesi }=10 \\
p=0.000\end{array}$} & \multirow{5}{*}{.90} & \multirow{5}{*}{.627} & \multirow{5}{*}{.892} \\
\hline & & IT1 & .868 & .86 & & & & & \\
\hline & & IT4 & .853 & .90 & & & & & \\
\hline & & IT5ters & .852 & .72 & & & & & \\
\hline & & IT3ters & .755 & .60 & & & & & \\
\hline \multirow{6}{*}{$\begin{array}{l}\text { İşe bağlı } \\
\text { gerginlik }\end{array}$} & \multirow{6}{*}{ Tek boyut } & IBG4 & .871 & .94 & \multirow{6}{*}{$\% 64.606$} & \multirow{6}{*}{$\begin{array}{l}\mathrm{KMO}=0,891 \\
\chi^{2}=2787.772 \\
\text { serbestlik } \\
\text { derecesi }=15 \\
\mathrm{p}=0.000\end{array}$} & \multirow{6}{*}{.887} & \multirow{6}{*}{.732} & \multirow{6}{*}{.942} \\
\hline & & IBG5 & .864 & .94 & & & & & \\
\hline & & IBG2 & .832 & .85 & & & & & \\
\hline & & IBG6 & .816 & .91 & & & & & \\
\hline & & IBG1 & .758 & .77 & & & & & \\
\hline & & IBG3 & .663 & .80 & & & & & \\
\hline & & DE2 & .913 & .90 & 1.faktör: & $\mathrm{KMO}=0.840$ & & & \\
\hline & $\begin{array}{l}\text { Deriniemesine } \\
\text { Eylem }\end{array}$ & $\mathrm{DE1}$ & .888 & .83 & $\% 49.017$ & $\chi^{2}=4965.898$ & & .718 & .884 \\
\hline & & DE3 & .875 & .81 & 2.faktör: & serbestlik & & & \\
\hline & & DE5 & .848 & .88 & $\% 23.336$ & derecesi $=36$ & & & \\
\hline $\begin{array}{l}\text { emek } \\
\text { emekal }\end{array}$ & Sahte Duygular & DE4 & 839 & .79 & 3.faktör: & $p=0.000$ & .867 & .724 & .887 \\
\hline & & DE6 & .820 & .88 & $\% 8.896$ & Varimax & & & \\
\hline & & DE8 & .862 & .90 & Üçü & döndürmesi & & & \\
\hline & Duygular & DE9 & .826 & .77 & birlikte & (Tekrar sayısı: & & .719 & .884 \\
\hline & & DE7 & .809 & .87 & $\% 81.249$ & & & & \\
\hline & & BP3 & .878 & 94 & & $\mathrm{KMO}=0,820$ & & & \\
\hline & & BP4 & .877 & .78 & & $\chi^{2}=2733,850$ & & & \\
\hline Performans & Tek boyut & BP1 & .839 & .78 & $\% 70.744$ & serbestlik & .895 & .584 & .873 \\
\hline & & BP5 & .828 & .66 & & derecesi=10 & & & \\
\hline & & BP2 & .780 & .62 & & $p=0,000$ & & & \\
\hline & & S4 & .819 & .670 & & $\mathrm{KMO}=0.822$ & & & \\
\hline Örgütlerin & & S2 & .804 & .647 & & $\chi^{2}=1457.582$ & & & \\
\hline Sıkılık & Tek boyut & S3 & .753 & .567 & $\% 58.826$ & serbestlik & .823 & .473 & .816 \\
\hline Durumu & & S5 & .751 & .564 & & derecesi $=10$ & & & \\
\hline & & S1 & .702 & .493 & & $p=0.000$ & & & \\
\hline & & AOD3 & 899 & .809 & & & & & \\
\hline & & AOD2 & .877 & .770 & & & & & \\
\hline & & AOD4 & .859 & .738 & & $\begin{array}{l}\mathrm{KMO}=0.919 \\
\gamma^{2}=232,926\end{array}$ & & & \\
\hline Örgütsel & Tek boyut & AOD1 & .829 & .688 & $\% 67.444$ & serbestlik & & .614 & .926 \\
\hline Destek & тек doyut & AOD8 & .829 & .688 & $\% 001.444$ & derecesi= 28 & .930 & .014 & \\
\hline & & AOD 10 & .779 & 607 & & $p=0.000$ & & & \\
\hline & & AOD9 & .778 & .606 & & & & & \\
\hline & & AOD5 & .700 & .490 & & & & & \\
\hline
\end{tabular}

KF: Keşfedici Faktör Analizi Faktör Yükleri; DF: Doğrulayıcı Faktör Analizi Faktör Yükleri; Açık. Var: Açıklanan Varyans; KMO: Kaiser-Meyer- Olkin testi; AVE: Average Variance Extracted; CR: Composite Reliability 
Tablo 2'de görüldüğü üzere, araştırmada kullanılan bütün ölçüm araçlarının KMO değerleri 0,50'den ve 0,70'ten (Leech vd., 2005) oldukça büyük değerler almıştır bu nedenle veri setimizin faktör analizi için yeterli büyüklükte olduğu söylenebilmektedir. Barlett küresellik testine ilişkin Ki-kare değerine ilişkin anlamlılık değeri $p=0.00<0,05$ olması nedeniyle araştırmamıza ilişkin veri setinin çok değişkenli normal dağılımdan geldiği söylenebilmektedir (Çokluk vd., 2012: 219). Çokluk ve arkadaşlarının (2012) önerdiği üzere faktör yüklerinin 0.32 değerinden oldukça yüksek olduğu görülmektedir. Araştırmada kullanılan ölçüm araçlarının faktör yapılarına ilişkin açıklanan varyans değerleri de Hair ve arkadaşlarının (2010) önerdiği gibi \%60 değerinden büyük oldukları tespit edilmiştir. Buna göre açıklanan varyansın yüksek olması, ilgili kavramın iyi ölçüldüğün bir kanıtı olarak (Büyüköztürk, 2002: 479) kabul edilebilir. Sonuç olarak model çerçevesinde ele alınan değişkenlerin orijinal ölçeklerine benzer şekilde faktör yapılarına sahip olduğu görülmüştür. Güvenilirlik analizleri neticesinde, algılanan örgütsel destek haricindeki diğer değişkenlerde içsel tutarlılık değerini azaltan ve maddeler arası herhangi bir sorunlu maddeye rastlanmamıştır ve ölçeklerde Cronbach Alpha>0,70 görüldügü gerekçesiyle (Hair vd., 2010: 124) içsel tutarlıklarının yüksek olduğu kanıtlanmıştır. Algılanan örgütsel destek ölçeğinde AOD6 ve AOD7 olarak ters kodlanan maddelerin diğer maddelerle korelasyonlarının çok düşük (0.174-0.194 gibi) olduğu ve düzeltilmiş maddetoplam puan korelasyonları düşük olduğundan ve bu maddeler silinirse ölçeğin Cronbach Alpha katsayısının yükseldiği görüldüğünden bu iki maddenin ölçekten çıkarılmasına karar verilmiştir. Çünkü Madde-Toplam puan korelasyonunun en az 0,20 olması gerekmektedir (Kalkan ve Kaya, 2007: 38). Bu nedenle analizlerde algılanan örgütsel destek ölçeğinin 8 maddesi kullanılarak devam edilmiştir. Yapı geçerliliğinin göstergesi olarak hesaplanan bütün ölçüm araçlarının AVE ve CR değerleri de Hair ve arkadaşlarının (2010: 693) belirttiği (AVE> 0.50; CR> 0.70), Huang ve arkadaşlarının, (2013: 219) kabul ettiği (AVE>0.40; CR>0.60) Yaşlıoğlu'nun (2017: 82) dile getirdiği (CR>AV) kriterleri sağlamakta ve doğrulayıcı faktör analizlerinin model uyum indeksleri Tablo 3 'tedir.

Tablo 3: Ölçeklerin Doğrulayıcı Faktör Analizine Ilişskin Model Uyum Indeksleri

\begin{tabular}{lccccccc}
\hline Referans uyum indeksi & $\mathbf{X}$ & $\mathbf{X} \mathbf{2} \mathbf{d f}$ & $\mathbf{I F I}$ & TLI & CFI & GFI & RMSEA \\
\hline İyi Uyum & $\mathrm{p}>0.05$ & $\leq 3$ & $\geq 0.95$ & $\geq 0.95$ & $\geq 0.95$ & $\geq 0.90$ & $\leq 0.05$ \\
Kabul Edilebilir Uyum & - & $\leq 4-5$ & $0.94-0.90$ & $0.94-0.90$ & $>0.90$ & $0.89-0.85$ & $0.05-0.08$ \\
BDHV modeli & $\mathrm{P}<0.05$ & 3.496 & 0.991 & 0.984 & 0.991 & 0.985 & 0.054 \\
IT modeli & $\mathrm{P}=0,213$ & 1.496 & 1.000 & 0.998 & 1.000 & 0.998 & 0.024 \\
IBG modeli & $\mathrm{P}<0.05$ & 2.563 & 0.996 & 0.992 & 0.996 & 0.986 & 0.058 \\
DE modeli & $\mathrm{P}<0.05$ & 2.693 & 0.992 & 0.988 & 0.992 & 0.984 & 0.044 \\
BP modeli & $\mathrm{P}<0.05$ & 4.437 & 0.999 & 0.987 & 0.999 & 0.998 & 0.063 \\
S modeli & $\mathrm{P}<0.05$ & 4.219 & 0.991 & 0.978 & 0.991 & 0.992 & 0.061 \\
AOD modeli & $\mathrm{P}<0.05$ & 3.544 & 0.993 & 0.986 & 0.993 & 0.985 & 0.054 \\
\hline
\end{tabular}

BDHV: Bireysel düzeyde hesap verebilirlik, IT: İş tatmini, IBG: İşe bağlı gerginlik, DE: Duygusal emek, BP: Bağlamsal performans, S: Sıkılık, AOD: Algılanan örgütsel destek

Tablo 3'te görüldüğü üzere doğrulayıcı faktör analizlerine ilişkin model uyum indekslerinin bazıları kabul edilebilir uyum değerleri bazıları ise iyi uyum değerleri arasında yer almaktadır (Browne ve Cudeck, 1993). Ölçüm araçlarının gerek literatürde belirtilen özgün faktör yapısı gerekse araştırmamızda keşfedici faktör analizi sonucunda tespit edilen faktör yapıları doğrulanmıştır. Çoklu doğrusallıkta değişkenlerin birbirleriyle çok yüksek derecede ilişkili (örneğin genellikle, 0.90 ve üstü) olduğu ifade edilmektedir (Hair vd., 2010: 197). 
Araştırmamızda çoklu bağlantı sorunu olup olmadığını sınamak için değişkenler arasındaki ikili ilişkiler incelenmiş, varyans artış faktörleri ve tolerans değerlerine bakılmıştır ve ilgili değerler Tablo 4'te gösterilmiştir.

Tablo 4: Çoklu Bağlantı Sorununa Ilişkin Analizler ve Değişkenler Arası Korelasyon Analizi

\begin{tabular}{lccccccccc}
\hline \multicolumn{1}{c}{ Değişkenler } & TD & VIF & $\mathbf{1}$ & $\mathbf{2}$ & $\mathbf{3}$ & $\mathbf{4}$ & $\mathbf{5}$ & $\mathbf{6}$ & $\mathbf{7}$ \\
\hline 1. BDHV &, 374 & 2,676 & 1,00 & & & & & & \\
2. IT &, 624 & 1,604 &,- 401 & 1,00 & & & & & \\
3. IBG &, 613 & 1,632 &, 522 &,- 549 & 1,00 & & & \\
4. DEK &, 807 & 1,239 &, 324 &,- 201 &, 272 & 1,00 & & & \\
5. BP &, 597 & 1,675 &, 605 &,- 124 &, 292 &, 310 & 1,00 & & \\
6. S &, 866 & 1,154 &, 262 &, 013 &, 075 &, 184 &, 180 & 1,00 & \\
7. AOD &, 783 & 1,278 &,- 030 &, 360 &,- 252 &, 134 &, 168 &, 173 & 1,00 \\
\hline Ortalama & & & 3,70 & 3,08 & 3,42 & 3,25 & 3,68 & 3,70 & 2,89 \\
Standart sapma & & & 0,96 & 1,19 & 1,04 & 0,83 & 1,03 & 0,87 & 1,05 \\
\hline
\end{tabular}

BDHV: Bireysel düzeyde hesap verebilirlik, IT: İş tatmini, IBG: İ̧e bağlı gerginlik, DE: Duygusal emek, BP: Bağlamsal performans, S: Sıkılık, AOD: Algılanan örgütsel destek; TD: Tolerans Değeri, VIF: Varyans Artış Faktörü

Tablo 4'e göre değişkenlerin tolerans değerlerinin 0,1'den büyük (Mertler ve Vannatta Reinhart, 2017: 172), VIF değerlerinin ise 10'dan düşük olduğundan (Gürbüz ve Şahin, 2016: 273) ve değişkenler arasındaki korelasyonlarda ise 0,90 değerini aşan bir durum saptanmadığından (Hair vd., 2010: 197) değişkenler arasında çoklu doğrusal bağlantı problemi yoktur.

\subsection{2. Örgütlerin Sıkılık Durumunun Düzenleyici Değişken Etkisi}

Sıkılık durumunun düzenleyici değişken etkisinin ölçüm modeli Şekil 2'de gösterilmektedir.

Şekil 2: Sıkılık Durumunun Düzenleyici Değişken Etkisine Ilişskin Ölçüm Modeli

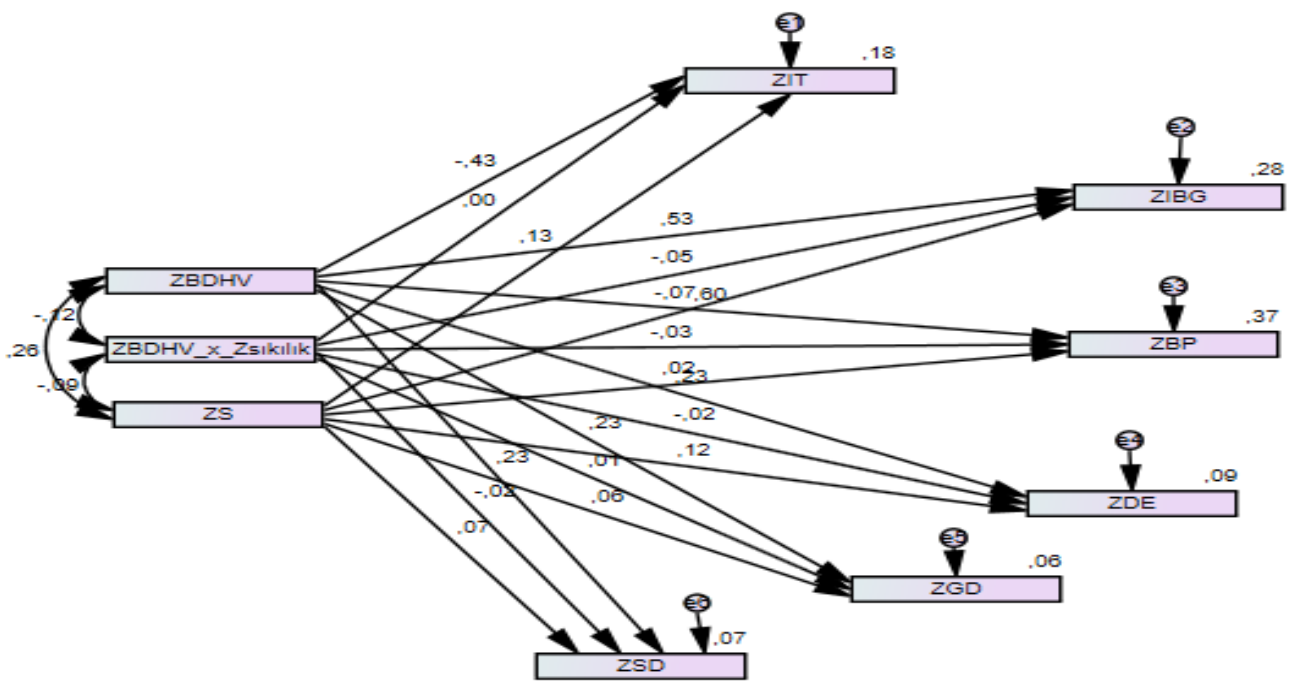

Şekil 2'de gösterilen modelin anlamlılığını saptamak amacıyla değişkenler arasındaki yolların anlamlııklarına bakılmıştır. Bireysel düzeyde hesap verebilirlik ve sıkılık değişkenin etkileşimi (ZBDHV_X_ZSIKILIK) ile bütün bağımlı değişkenler arasındaki yollar ile sıkılık kavramının bazı bağımlı değişkenler ile (bağlamsal performans, gizlenen duygular) arasındaki 
yollar istatiksel olarak anlamsız ( $p>0.05$ ) olduğu saptanmıştır. Böyle bir durumda, anlamlı olmayan yolların modelden sırasıyla çıkarılarak yeniden analiz yapılması (Meydan ve Şeşen, 2011: 109) öneri dikkate alınmıştır. Modelin nihai hali Şekil 3'te gösterilirken nihai modelin tahmin ve anlamlılıkları Tablo 5'te yer almaktadır.

Şekil 3: S Düzenleyici Değişken Modelinde Nihai Ölçüm Modeli

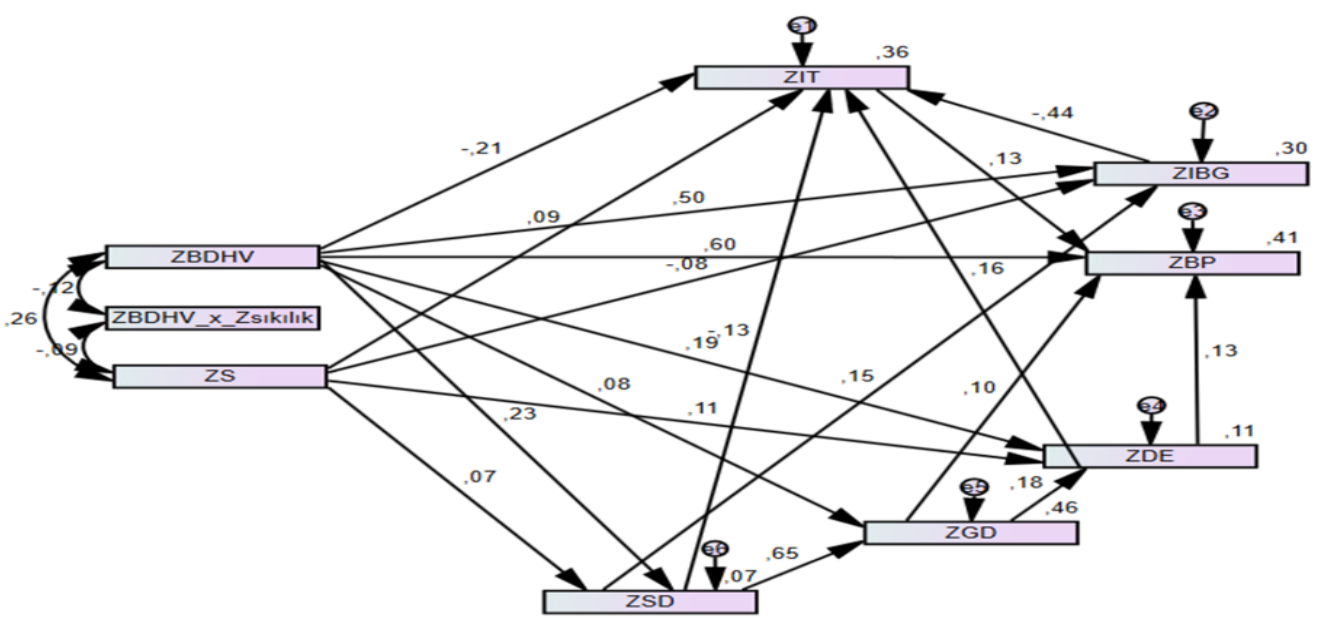

Tablo 5: S Düzenleyiciliğine İlişkin Nihai Ölçüm Modelindeki Tahmin ve Anlamlııklar

\begin{tabular}{lllllllll}
\hline \multicolumn{2}{c}{ Tahmin edilen yollar } & $(\mathbf{B})$ & $(\boldsymbol{\beta})$ & S. hata & Z değeri & $\mathbf{R}^{\mathbf{2}}$ & $\mathbf{P}$ \\
\hline ZSD & $<---$ & ZBDHV &, 232 &, 232 &, 034 & 6,802 & 0,067 & $* * *$ \\
ZSD & $<---$ & ZS &, 070 &, 070 &, 034 & 2,068 & 0,067 &, 039 \\
ZGD & $<---$ & ZBDHV &, 078 &, 078 &, 026 & 3,014 & 0,460 &, 003 \\
ZGD & $<---$ & ZSD &, 655 &, 655 &, 026 & 25,327 & 0,460 & $* * *$ \\
ZIBG & $<---$ & ZBDHV &, 504 &, 504 &, 030 & 16,612 & 0,299 & $* * *$ \\
ZDE & $<---$ & ZBDHV &, 194 &, 194 &, 034 & 5,689 & 0,114 & $* * *$ \\
ZIBG & $<---$ & ZS &,- 077 &,- 077 &, 030 & $-2,614$ & 0,299 &, 009 \\
ZDE & $<---$ & ZS &, 112 &, 112 &, 033 & 3,380 & 0,114 & $* * *$ \\
ZDE & $<---$ & ZGD &, 177 &, 177 &, 033 & 5,340 & 0,114 & $* * *$ \\
ZIBG & $<---$ & ZSD &, 154 &, 154 &, 030 & 5,227 & 0,299 & $* * *$ \\
ZIT & $<---$ & ZBDHV &,- 205 &,- 205 &, 034 & $-6,075$ & 0,363 & $* * *$ \\
ZIT & $<---$ & ZS &, 086 &, 086 &, 029 & 2,998 & 0,363 &, 003 \\
ZIT & $<---$ & ZIBG &,- 439 &,- 438 &, 033 & $-13,496$ & 0,363 & $* * *$ \\
ZIT & $<---$ & ZDE &, 164 &, 164 &, 029 & 5,721 & 0,363 & $* * *$ \\
ZIT & $<---$ & ZSD &,- 129 &,- 129 &, 029 & $-4,476$ & 0,363 & $* * *$ \\
ZBP & $<---$ & ZBDHV &, 601 &, 601 &, 030 & 19,921 & 0,412 & $* * *$ \\
ZBP & $<---$ & ZDE &, 126 &, 126 &, 028 & 4,506 & 0,363 & $* * *$ \\
ZBP & $<---$ & ZGD &, 099 &, 099 &, 028 & 3,568 & 0,412 & $* * *$ \\
ZBP & $<---$ & ZIT &, 134 &, 135 &, 029 & 4,618 & 0,412 & $* * *$ \\
\hline$* * *$
\end{tabular}

*** ile belirtilmek istenen $\mathrm{p}<0,001$ ifadesidir. B: Tahmin, $\beta$ : Standardize edilmiş tahmin, S. hata: Standart hata

Tablo 5'te yer alan bulgularda modeldeki bütün yollar $p<0.05$ olduğundan istatiksel olarak anlamlıdır. Değişkenlerin birbirleri üzerinde anlamlı etkiler söz konusuyken, düzenleyici değişkene ilişkin anlamlı yol olmadığından bireysel düzeyde hesap verebilirlik ve ardılları 
arasındaki ilişkilerde örgütlerin sıkılık durumunun düzenleyici değişken etkisinin olduğunu öneren $\mathrm{H} 1, \mathrm{H} 2, \mathrm{H} 3, \mathrm{H} 3 \mathrm{a}, \mathrm{H} 3 \mathrm{~b}, \mathrm{H} 3 \mathrm{c}$ ve $\mathrm{H} 4$ hipotezleri desteklenmemiştir. Modele ilişkin uyum indeksleri ise Tablo 6' da gösterilmektedir.

Tablo 6: S Düzenleyici Değişken Modelinde Nihai Ölçüm Modelinin Uyum Indeksleri

\begin{tabular}{lccc}
\hline \multicolumn{1}{c}{ Ölçüm } & Iyi Uyum & Kabul edilebilir Uyum & Modelin Uyum Indeksleri \\
\hline$\left(\chi^{2} / s d\right)$ & $\leq 3$ & $\leq 4-5$ & 1.427 \\
RMSEA & $\leq 0.05$ & $0.06-0.08$ & 0,022 \\
RMR & $0.00-0.05$ & $0.05-0.08$ & 0,015 \\
$\mathrm{NFI}$ & $\geq 0.95$ & $0.94-0.90$ & 0,990 \\
$\mathrm{CFI}$ & $\geq 0.97$ & $\geq 0.95$ & 0,997 \\
$\mathrm{GFI}$ & $\geq 0.90$ & $0.89-0.85$ & 0,995 \\
$\mathrm{AGFI}$ & $\geq 0.90$ & $0.89-0.85$ & 0,983 \\
TLI & $\geq 0.95$ & $0.94-0.90$ & 0,992 \\
\hline
\end{tabular}

Tablo 6'ya göre, bireysel hesap verebilirlik ve ardılları arasındaki yapısal eşitlik modellemesine ilişkin uyum indeksleri, $\chi 2=19.980$ S.d. $=14 \chi 2 /$ S.d. $=1.427, p=0,131$ olarak hesaplanmıştır. Düşük Ki-kare $(\chi 2)$ değerine sahip olması, önerilen modelin toplanan veriye uygun olduğunun (Anderson ve Gerbing, 1984: 156) göstergesidir. RMSEA $=0,022$, $\mathrm{RMR}=0,015, \mathrm{NFI}=0,990, \mathrm{CFI}=0,995, \mathrm{GFI}=0,995, \mathrm{AGFI}=0,983$ ve $\mathrm{TLI}=0,992$ olarak bulgulandığından model uyum indekslerinin hepsi iyi uyum gösterdiği (Browne ve Cudeck, 1993) söylenebilmektedir.

\subsubsection{Algılanan Örgütsel Desteğin Düzenleyici Değişken Etkisi}

Bireysel düzeyde hesap verebilirlik ve ardılları arasındaki ilişkilerde algılanan örgütsel desteğin düzenleyici değişken etkisinin olduğu varsayılan ölçüm modeli Şekil 4'te gösterilmektedir.

Şekil 4: AOD Düzenleyici Değişken Etkisine ilişskin Model

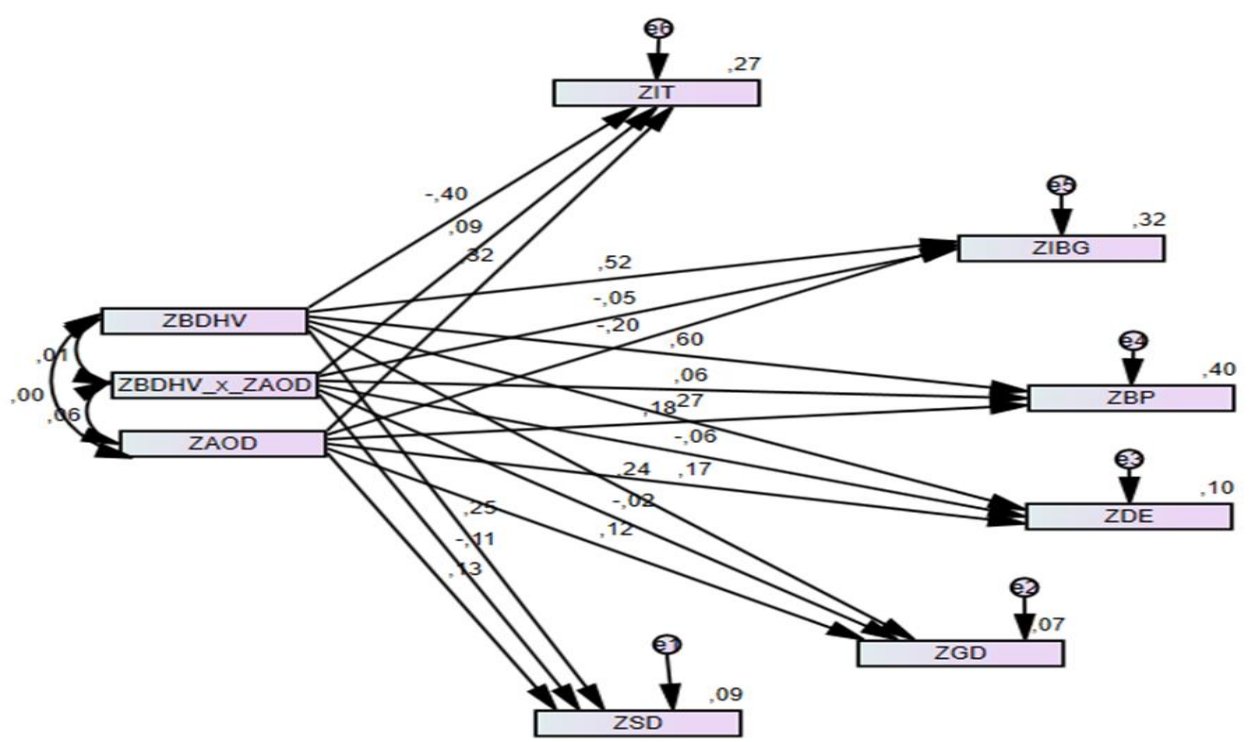


Şekil 4'te gösterilen modelin anlamlılığını saptamak amacıyla öncelikle değişkenler arasındaki yolların anlamlılıklarına bakılmıştır. Sonuçlara göre, bireysel düzeyde hesap verebilirlik ve algılanan örgütsel destek değişkenin etkileşimi (ZBDHV_X_ZAOD) ile gizlenen duygular $(p=0,450>0,05)$; işe bağlı gerginlik $(p=0,053>0,05)$; derinlemesine eylem $(p=0,051>0,05)$ arasındaki yollar istatiksel olarak anlamsız çıkmıştır. Bu çerçevede, H6. H7a. H7c. hipotezleri desteklenmemiştir. Anlamsız yollar çıkarıp analiz tekrardan yapıldığında algılanan örgütsel desteğin düzenleyicilik etkisine ilişkin modelin nihai hali Şekil 5 'te, model uyum değerleri Tablo 7'de, modelin anlamlılık değerleri ise Tablo 8'dedir.

\section{Şekil 5: AOD Düzenleyici Değişken Modelinde Nihai Ölçüm Modeli}

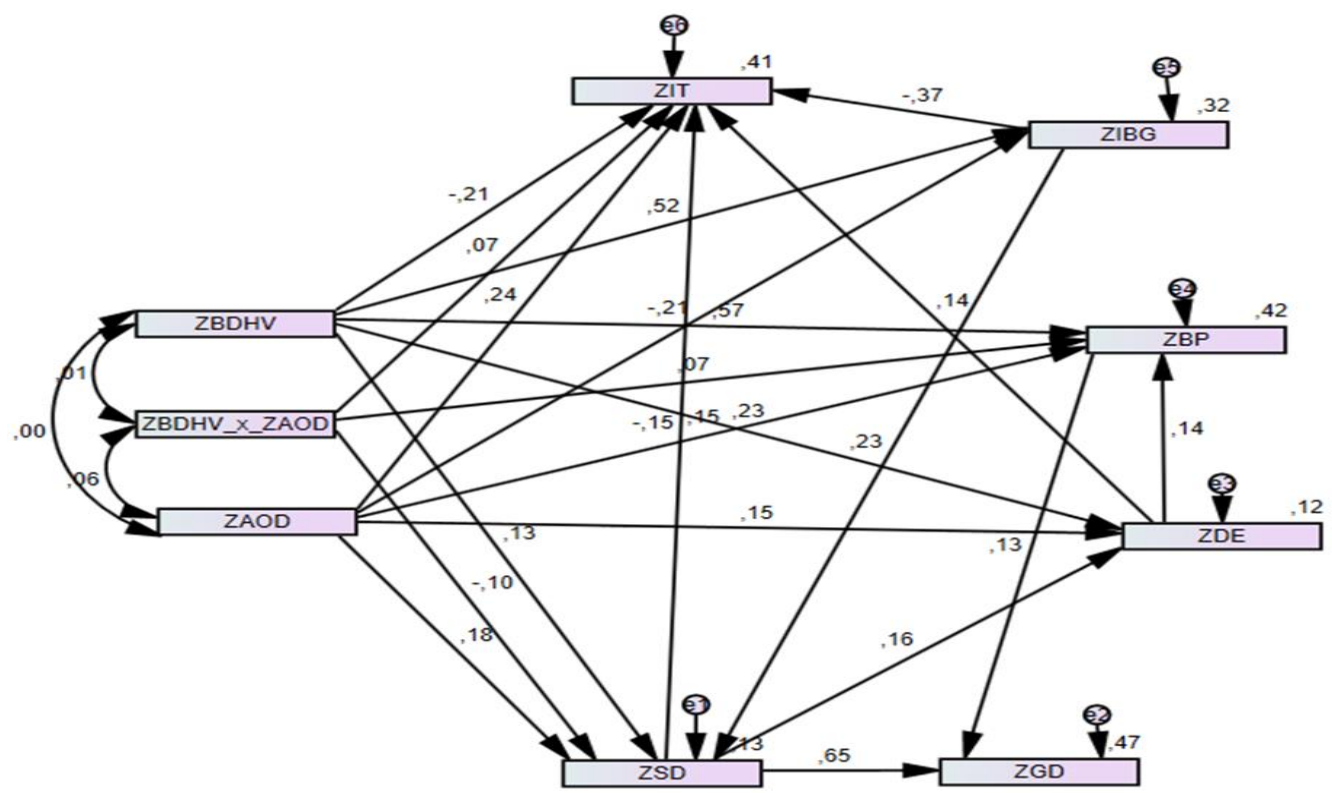

Tablo 7: AOD Düzenleyici Değişken Modelinde Nihai Ölçüm Modelinin Uyum Değerleri

\begin{tabular}{lccc}
\hline \multicolumn{1}{c}{ Ölçüm } & İyi Uyum & Kabul edilebilir Uyum & Modelin Uyum İndeksleri \\
\hline$\left(\chi^{2} / s d\right)$ & $\leq 3$ & $\leq 4-5$ & 2.198 \\
RMSEA & $\leq 0.05$ & $0.06-0.08$ & 0,037 \\
RMR & $0.00-0.05$ & $0.05-0.08$ & 0,018 \\
NFI & $\geq 0.95$ & $0.94-0.90$ & 0,987 \\
CFI & $\geq 0.97$ & $\geq 0.95$ & 0,993 \\
GFI & $\geq 0.90$ & $0.89-0.85$ & 0,993 \\
AGFI & $\geq 0.90$ & $0.89-0.85$ & 0,975 \\
TLI & $\geq 0.95$ & $0.94-0.90$ & 0,979 \\
\hline
\end{tabular}

Tablo 7'ye göre, algılanan örgütsel desteğin düzenleyici değişkene ilişkin nihai ölçüm modelinin uyum indeksleri, $\chi 2=26.376 ;$ s.d. $=12 \chi 2 / S . d .=2.198, p=0,009$ 'dır. Düşük Ki-kare $(\chi 2)$ değeri, önerilen modelin toplanan veriye uygun olduğunu (Anderson ve Gerbing, 1984: 156); $\mathrm{RMSEA}=0,037, \mathrm{RMR}=0,018, \mathrm{NFI}=0,987, \mathrm{CFI}=0,993, \mathrm{GFI}=0,993, \mathrm{AGFI}=0,975$ ve $\mathrm{TLI}=0,979$ değerleri model uyum indekslerinin iyi uyum gösterdiğinin (Browne ve Cudeck, 1993) kanıtıdır. 
Tablo 8: Algılanan Örgüt Desteğin Düzenleyiciliğine Iliş̧kin Nihai Modelin Anlamlılığı

\begin{tabular}{|c|c|c|c|c|c|c|c|c|}
\hline \multicolumn{3}{|c|}{ Tahmin edilen yollar } & \multirow{2}{*}{$\begin{array}{c}\text { Tahmin } \\
\text { (B) } \\
, 522\end{array}$} & \multirow{2}{*}{$\frac{\text { Stand.tahmin }(\boldsymbol{\beta})}{, 522}$} & \multirow{2}{*}{$\begin{array}{c}\text { S. hata } \\
, 028\end{array}$} & \multirow{2}{*}{$\frac{Z}{18,533}$} & \multirow{2}{*}{$\begin{array}{c}\mathbf{R}^{\mathbf{2}} \\
, 315\end{array}$} & \multirow{2}{*}{$\begin{array}{c}\mathbf{P} \\
* * *\end{array}$} \\
\hline ZIBG & $<--$ & ZBDHV & & & & & & \\
\hline ZIBG & $<--$ & ZAOD &,- 206 &,- 206 & 028 & $-7,303$ & 315 & $* * *$ \\
\hline ZSD & $<---$ & ZIBG & ,234 & ,234 & ,038 & 6,095 & 126 & $* * *$ \\
\hline ZSD & $<---$ & ZBDHV_x_ZAOD &,- 087 &,- 097 & 029 & $-3,041$ & 126 & ,002 \\
\hline ZSD & $<---$ & ZAOD & 181 & 181 & ,033 & 5,518 & 126 & $* * *$ \\
\hline ZSD & $<---$ & ZBDHV & 128 & 129 & 038 & 3,416 & 126 & $* * *$ \\
\hline ZDE & $<--$ & ZBDHV & ,226 & ,226 & 033 & 6,844 & 123 & $* * *$ \\
\hline ZDE & $<--$ & ZSD & 161 & 160 & ,033 & 4,825 & 123 & $* * *$ \\
\hline ZDE & $<--$ & ZAOD & 150 & 150 & ,032 & 4,661 & 123 & $* * *$ \\
\hline ZBP & $<--$ & ZBDHV & ,567 & ,567 & ,027 & 21,038 & ,420 & $* * *$ \\
\hline ZBP & $<--$ & ZBDHV_x_ZAOD & ,063 & ,070 & ,023 & 2,704 & ,420 & ,007 \\
\hline ZBP & $<---$ & ZAOD & 151 & 151 & 026 & 5,727 & ,420 & $* * *$ \\
\hline ZBP & $<---$ & ZDE & 140 & 140 & 027 & 5,117 & ,420 & $* * *$ \\
\hline ZIT & $<--$ & ZBDHV_x_ZAOD & ,060 & ,067 & ,024 & 2,534 & 411 & 011 \\
\hline ZIT & $<--$ & ZAOD & 239 & 239 & ,028 & 8,593 & 411 & $* * *$ \\
\hline ZIT & $<---$ & ZBDHV &,- 208 &,- 208 & ,032 & $-6,553$ & ,411 & $* * *$ \\
\hline ZIT & $<---$ & ZDE & 137 & 137 & 028 & 4,924 & ,411 & $* * *$ \\
\hline ZIT & $<--$ & ZIBG &,- 367 &,- 367 & ,032 & $-11,378$ & 411 & $* * *$ \\
\hline ZIT & $<---$ & ZSD &,- 154 &,- 154 & ,028 & $-5,434$ & 411 & $* * *$ \\
\hline ZGD & $<---$ & ZSD & ,651 & ,650 & ,025 & 25,780 & ,471 & $* * *$ \\
\hline ZGD & $<--$ & ZBP & 131 & 131 & ,025 & 5,182 & ,471 & $* * *$ \\
\hline
\end{tabular}

Tablo 8'e göre, bireysel hesap verebilirlik ve iş tatmini arasındaki $(R 2=0,411 ; \beta=0,067$; $p=0,011$ ) ilişkide algılanan örgütsel desteğin 0,05 anlamlılık düzeyinde, bireysel hesap verebilirlik ve sahte duygular arasındaki $(R 2=0,126 ; \beta=-0.097 ; p=0.002)$ ilişkide ve bireysel düzeyde hesap verebilirlik ve bağlamsal performans arasındaki ilişkide ( $R 2=0,420 ; \beta=-0.070$; $\mathrm{p}=0.007$ ) algılanan örgütsel desteğin 0.01 anlamlılık düzeyinde istatiksel açıdan anlamlı düzenleyici rolü tespit edilmiş ve $\mathrm{H} 5$ hipotezi, $\mathrm{H} 7 \mathrm{~b}$ hipotezi ve $\mathrm{H} 8$ hipotezi desteklenmiştir.

Şekil 6: BDHV ve IT Arasında AOD Düzenleyici Değiş̧keni

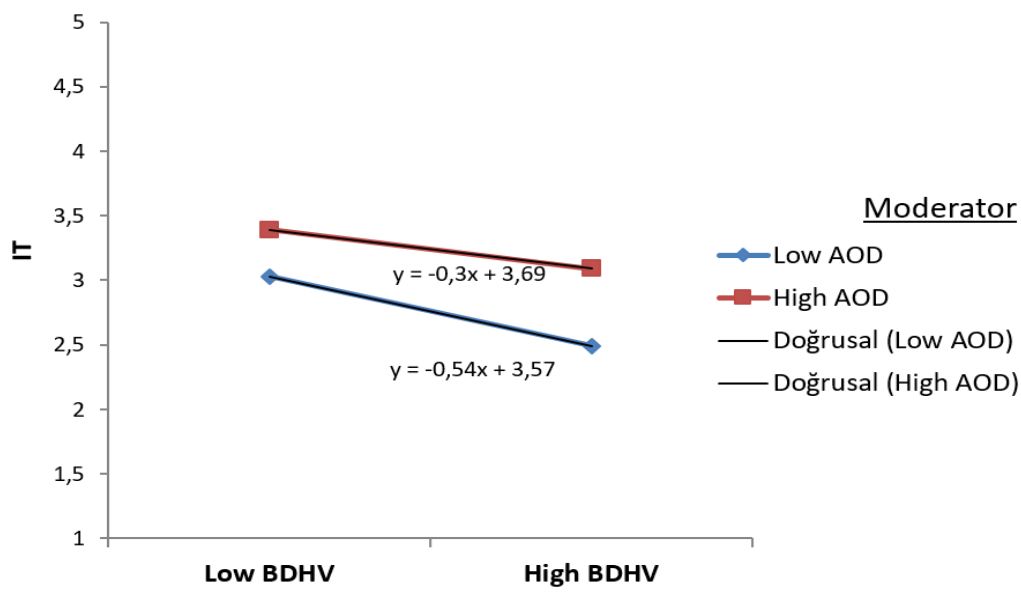


Şekil 6’ya göre, algılanan örgütsel destek, bireysel düzeyde hesap verebilirlik ve iş tatmini arasındaki negatif ilişkiyi azaltmaktadır.

Şekil 7: BDHV ve SD Arasında AOD Düzenleyici Değişken

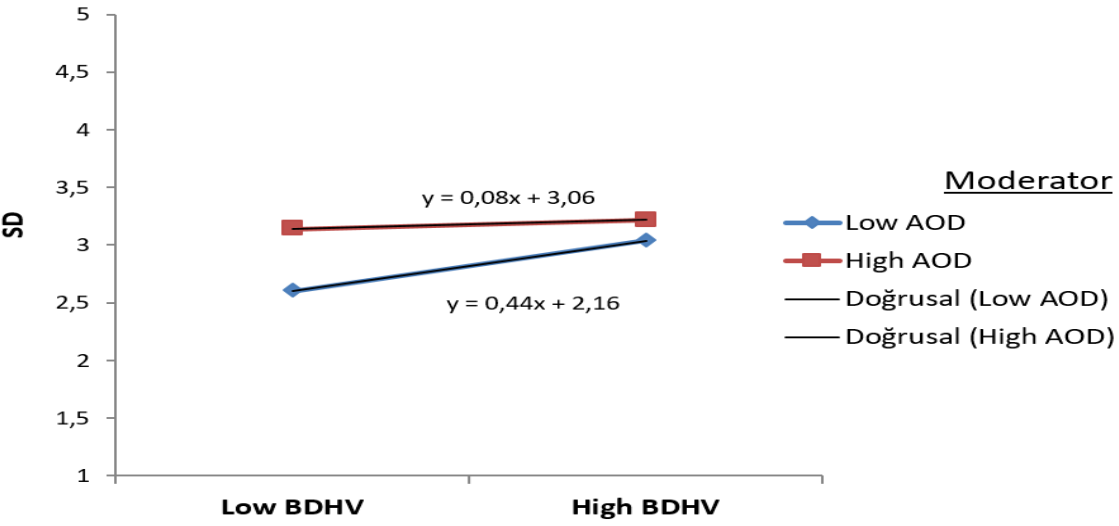

Şekil 8: BDHV ve BP arasında AOD düzenleyici değişkeni

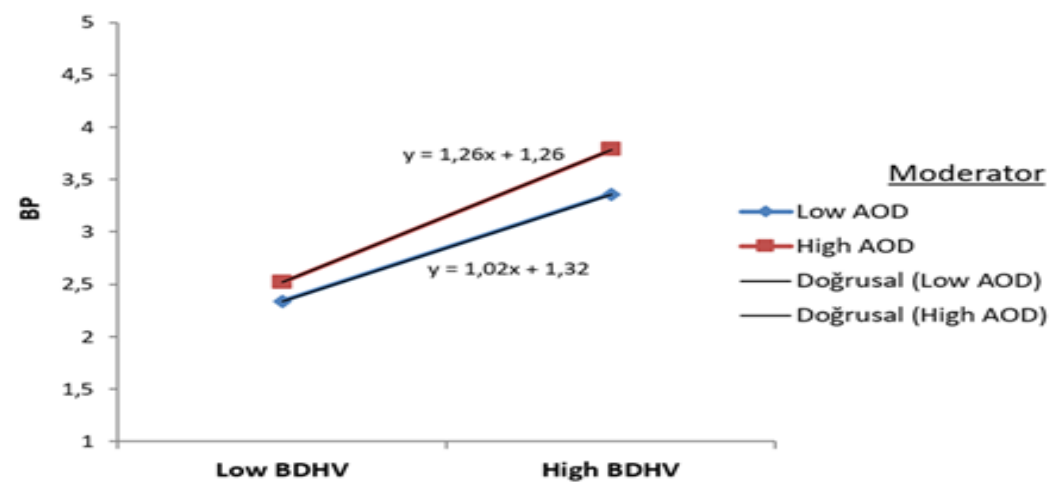

Şekil 7'e göre algılanan örgütsel destek bireysel düzeyde hesap verebilirlik ve sahte duygular arasındaki pozitif ilişkiyi azaltırken Şekil 8'e göre ise, bireysel hesap verebilirlik ve bağlamsal performans arasındaki ilişkiyi güçlendirdiği görülmektedir.

\section{Sonuç ve Tartışma}

$\mathrm{Bu}$ araştırma, hesap verebilirlik ve iş tatmini arasında negatif bir ilişkinin olduğu sonucunu paylaşan (Hall vd., 2006; Lanivich vd., 2010) çalışmalarıyla benzer sonuçlar gösterirken, hesap verebilirlik ve iş tatmini arasında pozitif bir ilişki bulgulayan (Specht, 1996; Thoms vd., 2002, Sorensen vd., 2009; Breaux vd., 2008; Breaux vd., 2009; Laird vd., 2009; Hall vd., 2009; Zellars vd., 2011; Wikhamn ve Hall, 2014; Laird vd., 2015; Royle, 2017) çalışmalarla örtüşmemektedir. Mevcut araştırmamız, (Ferris vd., 1995; Hall vd., 2003; Hochwarter vd., 2005; Hall vd., 2006; Hochwarter vd., 2007; Breaux vd., 2008; Laird vd., 2009; Zellars vd., 2011) çalışmalarıyla benzer şekilde hesap verebilirlik ve işe bağlı gerginlik arasında pozitif ilişki bulgulayarak bu çalışmaları desteklemektedir. Araştırmamızda bireysel hesap verebilirlik ve duygusal emek arasında pozitif bir ilişkinin ortaya çıkması, Hall ve arkadaşları (2003) çalışmasıyla ve Hall (2005) önerisiyle tutarlılık göstermektedir. Araştırmamızda bireysel hesap verebilirlik ve bağlamsal performans arasında pozitif bir ilişki saptanması ise Chen ve arkadaşları (2016) 
çalışmasıyla uyumludur. Örgütlerin sıkılık durumunun bazı değişkenler arasında düzenleyici etkisi olabileceğini belirten çalışmalar (Şen ve Basım, 2018a; Şen ve Basım, 2018b; Liu vd., 2018; Tang vd., 2019) olsa da araştırma bulgularımızda örgütlerin sıkılık durumunun istatiksel olarak bir düzenleyicilik etkisine rastlanmamıştır. Araştırmada bulguladığımız sonuç, alan yazında sıkılık-esnekliğin bazı değişkenler arasında düzenleyici rolü olmadığını bulgulayan (Altuncu, 2014; Lönnqvist, 2015; Şen ve Basım, 2018b; Şen vd., 2019) çalışmalarıyla benzerdir.

Araştırma bulgularımızda bireysel hesap verebilirlik ve iş tatmini arasındaki ilişkide algılanan örgütsel desteğin düzenleyici rolü olduğu bulgusu Wikhamn ve Hall (2014) çalışmasını destekler niteliktedir ve hesap verebilirliğin iş tatmini gibi ardıllar üzerindeki negatif etkilerin algılanan örgütsel destek kullanılarak iyileştirilebileceği (Hall, 2005: 52) önerisiyle uyuşmaktadır. Ayrıca bireysel hesap verebilirliğin; bağlamsal performans ve sahte duygularla olan ilişkisinde algılanan örgütsel desteğin düzenleyici rolü olduğunu bulgulamamız, alanyazında algılanan örgütsel desteğin, bazı değişkenler arasındaki ilişkilerde düzenleyici rolü olduğunu saptayan çalışmalar (Lynch vd., 1999; Stamper ve Johlke, 2003; Erdogan vd., 2004; Witt ve Carlson, 2006; Erdogan ve Enders, 2007; Butts vd., 2009; Nixon vd., 2011; Conway ve Coyle-Shapiro, 2012; Hur vd., 2015; Palmer vd., 2017; Sökmen vd., 2017; Chung, 2017; Cheng ve O-Yang, 2018; Uzunbacak vd., 2018; Işık, 2019; Acaray, 2019; Koçak, 2020) ile benzer sonuçlar göstermiştir. Bireysel hesap verebilirliğin işe bağlı gerginlik; derinlemesine eylem; gizlenen duygularla olan ilişkisinde algılanan örgütsel desteğin düzenleyici etkisi olmadığını bulgulamamı ise Butts vd., 2009; Gopalkrishnan (2011) ve Fettahlıoğlu ve Koca (2015) çalışmalarında algılanan örgütsel desteğin düzenleyici rolü bulmaması yönüyle benzerdir.

Mevcut araştırmamızla, bireysel düzeyde hesap verebilirlik kavramının ardılları ve düzenleyici değişkenleri hakkında bilgiler sunulmasının yanı sıra önerilen modelde bireysel ve örgütsel faktörlerin bir arada incelenmesi ile meso-düzeyde hesap verebilirlik literatürüne kayda değer katkı sağlanmaktadır.

\section{5. Öneriler}

Hastaneler, okullar veya bankalar gibi herhangi bir kurumsal örgütte sosyal düzen hakkında konuşurken hesap verebilirlik, önemli bir kavram olarak görüldügü̈nden birlikte yaşamanın bir aracı olarak, hesap verebilirliğin dinamiklerini anlamak temel bir gereksinimdir (Altuncu, 2014: 2). Politika geliştirenlerin, kural koyucuların ve uygulamaya geçirenlerin, demokratik hesap verebilirliği sağlamak için de yeni stratejilerin geliştirilmesi gerektiğinin (Kettl, 2002: 77) vurgulanması önemlidir. Çünkü, kamu-özel sektör tarafları arasındaki ilişkilerin değişikliğe uğraması, hesap verebilirlik sınırlandırmalarının yani, kimin, kıme karşı ne için hesap vereceği hususunun bulanıklaşmasına neden olacaktır (Diggs ve Roman 2012: 294) veya çoklu hesap verebilirlik sorununu ve gerginliği (Carnevale, 1985; Green vd., 2000: 1387) beraberinde getirecektir. Karmaşık iş birliklerinin olduğu örgütlerde ve ağlarda, hesap verebilirlikteki en küçük başarısızlıkların bile felaket sonuçlarına yol açabileceği (Diggs ve Roman, 2012: 308) göz ardı edilemeyecek bir sorun olduğundan politika geliştirenlerin, yöneticilerin bu hususa dikkat etmesi önem arz etmektedir.

Kamu-özel iş birliğinin, sağlık sektöründe örgüt yapısı, sağlık hizmetinin örgütlenmesine ilişkin planlama ve yönetsel karar süreçleri, çalışanların iş bölümü, denetim biçimi, güç ilişkileri, çalışma ilişkileri, özetle bir bütün olarak yönetim ilişkileri üzerinde etkileri olduğu (Karasu, 2011: 256) gerekçesiyle Şehir hastanelerindeki hibrit örgüt yapısının özelliklerine göre yönetişim standartlarının tanımlanması (Kızıltaş Uzunali ve Görmez, 2019: 1147) ve 
standartlar geliştirilirken bireysel hesap verebilirliğin; çalışanların eylemleri, davranışları ve tutumları üzerinde etkisi olduğu dikkate alınmasıyla hedeflenen başarımlara ulaşılabileceğini önerebiliriz. Nitekim, hesap verebilirliğin organizasyonların temel bir ilkesi olduğu ve bireylerin en azından belli bir dereceye kadar hesap verme konusunda sorumlu tutulmazsa örgütlerin etkili bir şekilde yürütülemeyeceği vurgulanmaktadır (Lerner ve Tetlock, 1999). Ancak, yüksek düzeyde bireysel hesap verebilirliğin de iş tatmininde azalma (Hall vd., 2006; Lanivich vd., 2010) ve işe bağlı gerginliği arttırmak (Ferris vd., 1995; Green vd., 2000; Hall vd., 2003; Hochwarter vd., 2005; Hall vd., 2006; Hochwarter vd., 2007; Breaux vd., 2008; Laird vd., 2009; Zellars vd., 2011) gibi negatif sonuçlara neden olduğu unutulmamalıdır. Ayrıca, bireylerin yüksek düzeyde hesap verebilirlik koşullarının olduğu ortamlarda aşırı derecede kontrol edildiğini hissettiği ve bunun da baskı ve gerilimin artmasına neden olabileceği (Hochwarter vd., 2005: 519) gözardı edilmemelidir. Bunlara ek olarak araştırmada ortaya konulan algılanan örgütsel desteğin bireysel hesap verebilirlik ve bazı ardıllar arasında düzenleyici etkisi olduğu sonucuna dayanarak ve örgütsel başarının sağlanmasında birincil unsurun; çalışanlar ve çalışanlar ile oluşturulacak ilişkilere dayandığı gerekçesiyle işgörenlere yönelik tasarlanan yönetimsel ilke ve politikalarda (Yetgin, 2016: 136) çalışanlar tarafından algılanan örgütsel desteğin dikkate alınması önerilmektedir. Ayrıca, araştırmada örgütlerin sıkılık durumunun bireysel hesap verebilirlik ve ardılları arasında herhangi bir düzenleyicilik etkisinin olmadığı sonucuna dayanarak, politika geliştirenlerin veya politikaları uygulayan yöneticilerin, çalışanlarının bireysel hesap verebilirliklerini güçlendirmek, geliştirmek, örgüt içinde hedeflenen amaçlarına ulaşmak (pozitif örgüt çıktılarını iş tatmini, performans, verimlilik vs. elde etmek) ve sürdürülebilir bir şekilde örgütün gelişimini sağlamak için kültürel olarak sıkı bir örgüt iklimi yerine esnek bir örgüt iklimi yaratmak için önlemler almaları gerektiği önerisine ek olarak çalışanlara odaklanan, çalışanların faydalarını ve beklentilerini gözeten, kişisel hak ve özgürlüklerini dikkate alarak karşılamaya çalışan destekleyici bir örgüt kültürünü benimsemelerinin örgütlerine daha fazla katkı sağlayabileceğini önerebiliriz. Bunlara ek olarak, bireysel hesap verebilirliğin "paylaşılan değerlerin ve inançların gerçekten bir yaşam tarzı olabileceğinin açık bir şekilde dile getirildiği bir örgüt kültürü” ile güçlendirilebileceği (Sinclair, 1995: 230) unutulmamalıdır.

Bireysel düzeyde hesap verebilirlikle ilgili yapılan ampirik çalışmaların çoğunda, öğrencilerin kullanıldığı ve laboratuvar deneyleri olarak yapıldığı (Frink ve Ferris, 1998; Lerner ve Tetlock, 1999; Frink ve Ferris, 1999; Green vd., 2000; Hochwarter vd., 2005; Hochwarter vd., 2007; Breaux vd., 2008; Laird vd., 2009) ve gerçek çalışma ortamında işgörenler üzerinde inceleyen az sayıda araştırma (Hall vd., 2003; Hall, 2005; Hall vd., 2006; Hall vd., 2009; Hall ve Ferris, 2011; Mero vd., 2014; Chen vd. 2016) olduğundan ileride yapılacak araştırmalarda, bireysel düzeyde hesap verebilirliğin öncülleri, ardılları, düzenleyici ve aracı değişkenlerini kapsayacak şekilde, farklı bağlamlarda incelenmesi alanyazına katkı sağlayacaktır. 


\section{Kaynakça}

Acaray, A. (2019), "Algılanan İş Güvencesizliğinin İş Performansına Etkisi: Örgütsel Desteğin Düzenleyici Rolü", Ufuk Üniversitesi, Sosyal Bilimler Enstitüsü Dergisi, C. 8, S. 16: 129-149.

Ali, N. (2008), "Factors Affecting Overall Job Satisfaction and Turnover Intention", Journal of Managerial Sciences, Vol. 2, No. 2: 239-252.

Altuncu, Y. (2014), "The Study of Mediation of Political Skill on the Relationship Between Psychological Collectivism and Felt Accountability through Contextual and Individual Factors", Doktora tezi, Marmara Üniversitesi, İstanbul.

Anderson, J. C., \& Gerbing, D. W. (1984), "The Effect of Sampling Error on Convergence, İmproper Solutions, and Goodness-of-Fit Indices for Maximum Likelihood Confirmatory Factor Analysis", Psychometrika, Vol. 49, No. 2: 155-173.

Antonioni, D. (1994), "The Effects of Feedback Accountability on Upward Appraisal Ratings", Personnel Psychology, Vol. 47, No. 2: 349-356.

Armstrong-Stassen, M., \& Ursel, N. D. (2009), “Perceived Organizational Support, Career Satisfaction, And The Retention of Older Workers", Journal of Occupational and Organizational Psychology, Vol. 82, No. 1: 201-220.

Beehr, T. A., \& Newman, J. E. (1978), “Job Stress, Employee Health, and Organizational Effectiveness: A Facet Analysis, Model, and Literature Review", Personnel Psychology, Vol. 31, No. 4: 665-699.

Borman, W. C., \& Motowidlo, S. J. (1993), "Expanding the Criterion Domain to Include Elements of Contextual Performance", In N. Schmitt \& W. C. Borman (Eds.), Personnel Selection in Organizations, San Francisco, CA: Jossey-Bass: 71-98.

Borman, W. C., \& Motowidlo, S. J. (1997), "Task Performance and Contextual Performance: The Meaning for Personnel Selection Research", Human Performance, Vol. 10, No. 2: 99-109.

Brayfield, A. H., \& Rothe, H. F. (1951), "An Index of Job Satisfaction”, Journal of Applied Psychology, Vol. 35, No. 5: 307-311.

Breaux, D. M., Munyon, T. P., Hochwarter, W. A., \& Ferris, G. R. (2009), "Politics as a Moderator of the Accountability-Job Satisfaction Relationship: Evidence across Three Studies", Journal of Management, Vol. 35, No. 2: 307-326.

Breaux, D. M., Perrewé, P. L., Hall, A. T., Frink, D. D., \& Hochwarter, W. A. (2008), "Time to Try a Little Tenderness? The Detrimental Effects of Accountability When Coupled with Abusive Supervision", Journal of Leadership \& Organizational Studies, Vol. 15, No. 2: 111-122.

Brotheridge, C. M., \& Lee, R. T. (2003), "Development and Validation of the Emotional Labour Scale", Journal of Occupational and Organizational Psychology, Vol. 76, No. 3: 365-379.

Browne, M. W., \& Cudeck, R. (1992), "Alternative Ways of Assessing Model Fit", Sociological Methods \& Research, Vol. 21, No. 2: 230-258.

Brunhart, A. D. (2013), "The Relationship Between Felt Accountability and Perceived Overall Organizational Performance in Federal Agencies", Doctoral dissertation, Walden University.

Butts, M. M., Vandenberg, R. J., DeJoy, D. M., Schaffer, B. S., \& Wilson, M. G. (2009), "Individual Reactions to High Involvement Work Processes: Investigating the Role of Empowerment and Perceived Organizational Support", Journal of Occupational Health Psychology, Vol. 14, No. 2: 122-136.

Büyüköztürk, Ş. (2002), “Faktör Analizi: Temel Kavramlar ve Ölçek Geliştirmede Kullanımı”, Kuram ve Uygulamada Eğitim Yönetimi Dergisi, C. 8, S. 4: 470-483.

Carnevale, P. J. D. (1985), “Accountability of Group Representatives and Intergroup Relations”, In E. J. Lawler (Eds.), Advances in Group Processes, Volume 2, Greenwich, CT: JAI Press.

Chen, C. H. V., Yuan, M. L., Cheng, J. W., \& Seifert, R. (2016), "Linking Transformational Leadership and Core SelfEvaluation to Job Performance: The Mediating Role of Felt Accountability", The North American Journal of Economics and Finance, Vol. 35, No. 2016: 234-246.

Cheng, J. C., \& O-Yang, Y. (2018), “Hotel Employee Job Crafting, Burnout and Satisfaction: The Moderating Role of Perceived Organizational Support”, International Journal of Hospitality Management, Vol. 72, No. 2018: 78-85.

Chou, C.-P., \& Bentler, P. M. (1995), “Estimates and Tests in Structural Equation Modeling”, In R. H. Hoyle (Ed.), Structural Equation Modeling: Concepts, Issues, and Applications, Thousand Oaks, London, New Delhi: Sage Publications, Inc. 


\section{Eskişehir Osmangazi Üniversitesi İktisadi ve İdari Bilimler Fakültesi Dergisi}

Chung, Y. W. (2017), "The Role of Person-Organization Fit and Perceived Organizational Support in the Relationship Between Workplace Ostracism and Behavioral Outcomes", Australian Journal of Management, Vol. 42, No. 2: 328-349.

Conway, N., \& Coyle-Shapiro, J. A. M. (2012), "The Reciprocal Relationship between Psychological Contract Fulfilment and Employee Performance and the Moderating Role of Perceived Organizational Support and Tenure", Journal of Occupational and Organizational Psychology, Vol. 85, No. 2: 277-299.

Cottrell, N. B. (1972), "Social Facilitation”, In C. G. McClintock (Eds.), Experimental Social Psychology. New York: Holt, Rinehart \& Winston.

Cummings, L. L., \& Anton, R. J. (1990), "The Logical and Appreciative Dimensions of Accountability", In S. Srivastva \& D. L. Cooperrider (Eds.), The Jossey-Bass Management Series, Appreciative Management and Leadership: The Power of Positive Thought and Action in Organizations, 257-286, Jossey-Bass.

Çelik, P., \& Topsakal, Y. (2016), “Duygusal Emeğin İş Tatmini ve Duygusal Tükenme ile iliş̧kisi: Antalya Destinasyonu Otel Çalışanları Örneği", İşletme Araştırmaları Dergisi, C. 8, S. 4: 202-218.

Çokluk, Ö., Şekercioğlu, G. ve Büyüköztürk, ş. (2012), "Sosyal Bilimler İçin Çok Değişkenli İstatistik: SPSS ve LISREL Uygulamaları", 2. baskı. Ankara: Pegem Akademi.

Dawley, D., Houghton, J. D., \& Bucklew, N. S. (2010), "Perceived Organizational Support and Turnover Intention: The Mediating Effects of Personal Sacrifice and Job Fit", The Journal of Social Psychology, V. 150, N. 3: 238-257.

Diggs, S. N., \& Roman, A. V. (2012), "Understanding and Tracing Accountability in the Public Procurement Process: Interpretations, Performance Measurements, and the Possibility of Developing Public-Private Partnerships", Public Performance \& Management Review, Vol. 36, No. 2: 290-315.

Donaldson, L., \& Davis, J. H. (1991), "Stewardship Theory or Agency Theory: CEO Governance and Shareholder Returns", Australian Journal of Management, Vol. 16, No. 1: 49-64.

Dursun, S., Aytaç, S., \& Bayram, N. (2014). Duygusal Emek Ölçeği Türkçe Formunun Geçerlilik ve Güvenilirlik Çalışması. İş, Güç" Endüstri İlişkileri ve İnsan Kaynakları Dergisi, C. 16, S. 2: 10-18.

Eisenberger, R., Cummings, J., Armeli, S., \& Lynch, P. (1997), "Perceived Organizational Support, Discretionary Treatment, and Job Satisfaction", Journal of Applied Psychology, Vol. 82, No. 5: 812-820.

Eisenberger, R., Huntington, R., Hutchison, S., \& Sowa, D. (1986), “Perceived Organizational Support. Journal of Applied Psychology", Vol. 71, No. 3: 500-507.

Emanuel, E. J., \& Emanuel, L. L. (1996), “What is Accountability in Health Care?”, Annals of Internal Medicine, Vol. 124, No. 2: 229-239.

Erdogan, B., Kraimer, M. L., \& Liden, R. C. (2004), "Work Value Congruence and Intrinsic Career Success: The Compensatory Roles of Leader-Member Exchange and Perceived Organizational Support", Personnel Psychology, Vol. 57, No. 2: 305-332.

Erdoğan, B., \& Enders, J. (2007), "Support from the Top: Supervisors' Perceived Organizational Support as a Moderator of Leader-Member Exchange to Satisfaction and Performance Relationships", Journal of Applied Psychology, Vol. 92, No. 2: 321-330.

Fandt, P. M., \& Ferris, G. R. (1990), "The Management of Information and Impressions: When Employees Behave Opportunistically", Organizational Behavior and Human Decision Processes, Vol. 45, No. 1: 140-158.

Ferris, G. R., Dulebohn, J. H., Frink, D. D., George-Falvy, J., Mitchell, T. R., \& Matthews, L. M. (1997), Job and Organizational Characteristics, Accountability, and Employee İnfluence. Journal of Managerial Issues, Vol. 9, No. 2: $162-175$.

Ferris, G. R., Mitchell, T. R., Canavan, P. J., Frink, D. D., \& Hopper, H. (1995), “Accountability in Human Resource Systems", In G. R. Ferris, S. D. Rosen, \& D. T. Barnum (Eds.), Handbook of Human Resource Management, Oxford, UK: Blackwell: 175-196.

Fettahlıoğlu, Ö. O., \& Koca, N. (2015), “Örgütsel Özdeşleşme ve Örgütsel Vatandaşlık ilişkisinde Örgütsel Desteğin Düzenleyici Etkisi, Sosyal Bilimler Dergisi, C. 2, S. 4: 218-234.

Frink, D. D., \& Ferris, G. R. (1998), “Accountability, Impression Management, and Goal Setting in the Performance Evaluation Process, Human Relations, Vol. 51, No. 10: 1259-1283.

Frink, D. D., \& Ferris, G. R. (1999), "The Moderating Effect of Accountability on the Conscientiousness-Performance Relationships", Journal of Business and Psychology, Vol. 13, No. 4: 515-524. 
Frink, D. D., \& Klimoski, R. J. (1998), "Toward a Theory of Accountability in Organizations and Human Resource Management", In G. R. Ferris (Eds.), Research in Personnel and Human Resources Management, Stamford, CT: Elsevier Science/JAI Press, Vol. 16: 1-51.

Gelfand, M. J., Nishii, L. H., \& Raver, J. L. (2006), "On the nature and importance of cultural tightness-looseness", Journal of Applied Psychology, Vol. 91, No. 6: 1225- 1244.

Goodman, J. M., Evans, W. R., \& Carson, C. M. (2011), “Organizational Politics and Stress: Perceived Accountability as a Coping Mechanisms, The Journal of Business Inquiry, Vol. 10, No. 1: 66-80.

Gopalkrishnan, P. (2011), "Workplace Incivility and Employee Strain Reactions: The Moderating Effects of Perceived Organizational Support and Job İnsecurity", Doctoral dissertation, Bowling Green State University.

Green, M. C., Visser, P. S., \& Tetlock, P. E. (2000), “Coping with Accountability Cross-Pressures: Low-Effort Evasive Tactics and High-Effort Quests for Complex Compromises", Personality and Social Psychology Bulletin, Vol. 26, No. 11: 1380-1391.

Gürbüz, S., \& Şahin, F. (2016), "Sosyal Bilimlerde Araştırma Yöntemleri”, Ankara: Seçkin Yayıncılık.

Hair, J. F. Jr., Black, W. C. Babin, B. J. \& Anderson, R. E. (2010), “Multivariate Data Analysis”, Seventh Ed., New Jersey: Prentice-Hall International Inc.

Hall, A. T. (2005), "Accountability in Organizations: An examination of Antecedents and Consequences", Doctoral dissertation, The Florida State University, College of Business.

Hall, A. T., \& Ferris, G. R. (2011), “Accountability and extra-role behaviors”, Employee Responsibilities and Rights Journal, Vol. 23, No. 2: 131-144.

Hall, A. T., Frink, D. D., \& Buckley, M. R. (2017), “An Accountability Account: A review and Synthesis of the Theoretical and Empirical Research on Felt Accountability", Journal of Organizational Behavior, Vol. 38, No. 2: 204-224.

Hall, A. T., Frink, D. D., Ferris, G. R., Hochwarter, W. A., Kacmar, C. J., \& Bowen, M. G. (2003), "Accountability in Human Resources Management", In C. A. Schriesheim \& L. Neider (Eds.), New directions in Human Resource Management, Greenwich, CT: Information Age Publishing: 29-63.

Hall, A. T., Royle, M. T., Brymer, R. A., Perrewé, P. L., Ferris, G. R., \& Hochwarter, W. A. (2006), "Relationships Between Felt Accountability as a Stressor and Strain Reactions: The Neutralizing Role of Autonomy Across Two Studies", Journal of Occupational Health Psychology, Vol. 11, No. 1: 87-99.

Hall, A. T., Zinko, R., Perryman, A. A., \& Ferris, G. R. (2009), “Organizational Citizenship Behavior and Reputation: Mediators in the Relationships Between Accountability and Job Performance and Satisfaction", Journal of Leadership \& Organizational Studies, Vol. 15, No. 4: 381-392.

Hochwarter, W. A., Ferris, G. R., Gavin, M. B., Perrewé, P. L., Hall, A. T., \& Frink, D. D. (2007), "Political Skill as Neutralizer of Felt Accountability-Job Tension Effects on Job Performance Ratings: A longitudinal Investigation", Organizational Behavior and Human Decision Processes, Vol. 102, No. 2: 226-239.

Hochwarter, W. A., Kacmar, C. J., \& Ferris, G. R. (2003), "Accountability at Work: An Examination of Antecedents and Consequences". Paper presented at the annual meeting of the Society of Industrial and Organizational Psychology, Orlando, FL.

Hochwarter, W. A., Perrewé, P. L., Hall, A. T., \& Ferris, G. R. (2005), “Negative Affectivity as a Moderator of the Form and Magnitude of the Relationship Between Felt Accountability and Job Tension", Journal of Organizational Behavior: The International Journal of Industrial, Occupational and Organizational Psychology and Behavior, Vol. 26, No. 5: 517-534.

House, R. J., \& Rizzo, J. R. (1972), "Role Conflict and Ambiguity as Critical Variables in a Model of Organizational Behaviors", Organizational Behavior and Human Performance, Vol. 7, No. 3: 467-505.

Huang, C. C., Wang, Y. M., Wu, T. W., \& Wang, P. A. (2013), “An Empirical Analysis of the Antecedents and Performance Consequences of Using The Moodle Platform", International Journal of Information and Education Technology, Vol. 3, No. 2: 217-221.

Hur, W. M., Han, S. J., Yoo, J. J., \& Moon, T. W. (2015), "The Moderating Role of Perceived Organizational Support on the Relationship Between Emotional Labor and Job-Related Outcomes", Management Decision, Vol. 53, No. 3: 605-624.

Işık, M. (2019), "Algılanan Aşırı Vasıflılık ve Bireysel Kariyer Planlaması illişkisinde algılanan Örgütsel Desteğin Düzenleyicilik Etkisi", Bingöl Üniversitesi, Sosyal Bilimler Enstitüsü Dergisi, C. 9, S. 18: 1015-1041.

Jawahar, I. M., \& Carr, D. (2007), “Conscientiousness and Contextual Performance, Journal of Managerial Psychology, Vol. 22, No. 4: 330-349. 


\section{Eskişehir Osmangazi Üniversitesi İktisadi ve İdari Bilimler Fakültesi Dergisi}

Jensen, M., \& Meckling, W. (1976), "Theory of the Firm: Management Behavior, Agency Costs and Capital Structure", Journal of Financial Economics, Vol. 3, No. 4: 305-60.

Judge, T., Locke, E., Durham, C., \& Kluger, A. (1998), "Dispositional Effects on Job and Life Satisfaction: The Role of Core Evaluations", Journal of Applied Psychology, Vol. 83, No. 1: 17-34.

Kalkan, M., \& Kaya, S. N. (2007), "Evlilik Öncesi iliş̧kileri Değerlendirme Ölçeğinin (EÖiDÖ) Gelişirilmesi: Geçerlik ve Güvenirlik Çalışması", Sosyal Politika Çalışmaları Dergisi, C. 3, S. 11: 35-40.

Karakurum, M. (2005), "The Effects of Person-Organization Fit on Employee Job Satisfaction, Performance and Organizational Commitment in A Turkish Public Organization", Yayınlanmamış Yükseklisans Tezi, Orta Doğu Teknik Üniversitesi, Ankara.

Karasu, K. (2011), "Sağı̆ık Hizmetlerinin Örgütlenmesinde Kamu-Özel Ortaklığı", Ankara Üniversitesi SBF Dergisi, C. 66, S. 3: 217-262.

Katz, D., \& Kahn, R. L. (1978), “The Social Psychology of Organizations”, 2nd ed., New York: John Wiley.

Keay, A. (2017), "Stewardship theory: Is Board Accountability Necessary?", International Journal of Law and Management, Vol. 59, No. 6: 1292-1314.

Kerman, U., Altan, Y., Aktel, M., \& Eke, E. (2012), "Sağlık Hizmetlerinde Kamu Özel Ortaklığı Uygulaması”, Süleyman Demirel Üniversitesi İktisadi ve İdari Bilimler Fakültesi Dergisi, C. 17, S. 3: 1-23.

Kettl, D. F. (2002), "The Transformation of Governance, Public Administration for Twenty-First Century America", Baltimore \& London: Johns Hopkins University Press.

Khandwalla, P. N. (1976), "Some Top Management Styles, Their Context and Performance", Organization and Administrative Sciences, Vol. 7, No. 4: 21-51.

Kılıç, K.C., Toker, I. D., Karayel, D., Soyman, T., \& Zengin, G. (2020), “Paternalist ve Dönüşümsel Liderlik Tarzlarının İşe Adanmışık Üzerindeki Etkisinde, Sıkılık-Esneklik Değişkeninin Aracılık Rolü", OPUS Uluslararası Toplum Araştırmaları Dergisi, C. 15, S. 24: 2875-2911.

Kızıltaş Uzunali, E., \& Görmez, A. H. (2019), “Devlet Bütçesi Açısından Kamu Özel İşbirliği Projelerinde Hibrid Yönetişim Standartlarının Geliştirilmesinin Önemi", Journal of International Social Research, C. 12, S. 65: 1133-1148.

Koçak, D. (2020), "İ̧̧ özerkliği ile işe bağlanma arasındaki ilişki: Kişi-iş uyumunun aracı ve algılanan yönetici desteğinin düzenleyici rolü”, Eskişehir Osmangazi Üniversitesi, iliBF Dergisi, C. 15, N. 2: 699 - 718.

Kromm, S. K. (2014), “Accountability in Ontario's Acute Care Hospital Sector and Its Effect on Organizational Strategic Priorities", Doctoral dissertation, University of Toronto.

Kurtessis, J. N., Eisenberger, R., Ford, M. T., Buffardi, L. C., Stewart, K. A., \& Adis, C. S. (2017), "Perceived Organizational Support: A Meta-Analytic Evaluation of Organizational Support Theory", Journal of Management, Vol. 43, No. 6: 1854-1884.

Laird, M. D., Harvey, P., \& Lancaster, J. (2015), “Accountability, Entitlement, Tenure, and Satisfaction in Generation $Y^{\prime \prime}$, Journal of Managerial Psychology, Vol. 30, No. 1: 87-100.

Laird, M. D., Perryman, A. A., Hochwarter, W. A., Ferris, G. R., \& Zinko, R. (2009), "The Moderating Effects of Personal Reputation on Accountability-Strain Relationships", Journal of Occupational Health Psychology, Vol. 14, No. 1: 70-83.

Lanivich, S. E., Brees, J. R., Hochwarter, W. A., \& Ferris, G. R. (2010), "PE Fit as Moderator of the AccountabilityEmployee Reactions Relationships: Convergent Results across Two Samples", Journal of Vocational Behavior, Vol. 77, No. 3: 425-436.

Lee, R. T., \& Brotheridge, C. M. (2006), "Validation and Extension of the Emotional Labor Scale: Evidence from DayCare Workers". Paper presented at the International Conference on Emotions and Work- Life, August, Atlanta, GA.

Lee, R. T., \& Brotheridge, C. M. (2011), "Words from the Heart Speak to the Heart", Career Development International, Vol. 6, No. 4: 401-420.

Leech, N. L., Barrett, K. C., \& Morgan, G. A. (2005), "SPSS for Intermediate Statistics: Use and Interpretation”, Second edition, Mahwah, New Jersey, London: Lawrence Erlbaum Associates, Publishers.

Lerner, J. S., \& Tetlock, P. E. (1999), “Accounting for the Effects of Accountability”, Psychological Bulletin, Vol. 125, No. 2: 255-275.

Liu, P., Chan, D., Qiu, L., Tov, W., \& Tong, V. J. C. (2018), “Effects of Cultural Tightness-Looseness and Social Network Density on Expression of Positive and Negative Emotions: A Large-Scale Study of Impression Management by Facebook Users", Personality and Social Psychology Bulletin, Vol. 44, No. 11: 1567-1581. 
Lönnqvist, C. (2015), "Values and Behaviour in the Context of Culture: The Moderating effect of Cultural TightnessLooseness on Value-Behaviour Associations in 18 European Countries", Master's thesis, University of Helsinki.

Lusch, R. F., \& Serpkenci, R. R. (1990), "Personal Differences, Job Tension, Job Outcomes, and Store Performance: A Study of Retail Store Managers" Journal of Marketing, Vol. 54, No. 1: 85-101.

Lynch, P. D., Eisenberger, R., \& Armeli, S. (1999), "Perceived Organizational Support: Inferior versus Superior Performance by Wary Employees", Journal of Applied Psychology, Vol. 84, No. 4: 467-483.

Mero, N. P., Guidice, R. M., \& Werner, S. (2014), "A Field Study of the Antecedents and Performance Consequences of Perceived Accountability", Journal of Management, Vol. 40, No. 6, 1627-1652.

Mertler, C. A., \& Vannatta Reinhart, R. (2017), “Advanced and Multivariate Statistical Methods: Practical Application and Interpretation", Sixth edition, New York: Routledge Taylor \& Francis.

Meydan, C. H. \& Şeşen, H. (2011), "Yapısal Eşitlik Modellemesi AMOS Uygulamaları", 1. Baskı, Ankara: Detay Yayıncilık.

Mitchell, T. R. (1993), "Leadership, Values and Accountability", In M. M. Chemers \& R. Ayman (Eds.), Leadership Theory and Research: Perspectives and Directions, 109-136, San Diego, CA: Academic Press.

Mitchell, T. R., Hopper, H., Daniels, D., George, J., Gerald, F., \& Ferris, R. (1998), "Power, Accountability, And Inappropriate Actions", Applied Psychology: An International Review, Vol. 47, No. 4: 497-517.

Nixon, A. E., Yang, L. Q., Spector, P. E., \& Zhang, X. (2011), “Emotional Labor in China: Do Perceived Organizational Support and Gender Moderate the Process?", Stress and Health, Vol. 27, No. 4: 289-305.

Ouchi, W. G. (1977), "The Relationship Between Organizational Structure And Organizational Control”, Administrative Science Quarterly, Vol. 22, No. 1: 95-113.

Palmer, J. C., Komarraju, M., Carter, M. Z., \& Karau, S. J. (2017), “Angel on One Shoulder: Can Perceived Organizational Support Moderate the Relationship Between the Dark Triad Traits and Counterproductive Work Behavior?", Personality and Individual Differences, Vol. 110: 31-37.

Quinn, A., \& Schlenker, B. R. (2002), "Can Accountability Produce Independence? Goals as Determinants of the Impact of Accountability on Conformity", Personality and Social Psychology Bulletin, Vol. 28, No. 4: 472-483.

Royle, M. T. (2017), "The Mediating Effect of Felt Accountability on the Relationship Between Personality and Job Satisfaction, International Journal of Management and Marketing Research, Vol. 10, No. 1: 19-44.

Schillemans, T., \& Busuioc, M. (2015), "Predicting Public Sector Accountability: From Agency Drift to Forum Drift", Journal of Public Administration Research and Theory, Vol. 25, No. 1: 191-215.

Schlenker, B. R., \& Weigold, M. F. (1989), "Self-Identification and Accountability", In R. A. Giacalone \& P. Rosenfeld (Eds.), Impression Management in the Organization, Hillsdale, NJ: Erlbaum: 21-43.

Schlenker, B. R., Britt, T. W., Pennington, J., Murphy, R., \& Doherty, K. (1994), "The Triangle Model of Responsibility". Psychological Review, Vol. 101, No. 4: 632-652.

Schlenker, B. R., Miller, M. L., \& Johnson, R. M. (2009), “Moral Identity, Integrity, and Personal Responsibility”, In D. Narvaez \& D. K. Lapsley (Eds.), Personality, Identity, and Character, New York, NY: Cambridge University Press: 316-340.

Schlenker, B. R., Pontari, B. A., \& Christopher, A. N. (2001), "Excuses and Character: Personal and Social Implications of Excuses", Personality and Social Psychology Review, Vol. 5, No. 1: 15-32.

Sinclair, A. (1995). The Chameleon of Accountability: Forms and Discourses. Accounting, Organizations and Society, 20(2-3), 219-237.

Sonnentag, S., Volmer, J. and Spychala, A. (2008), "Job Performance", In Barling, J. and Cooper, C.L. (Eds), The SAGE Handbook of Organizational Behavior, Volume One: Micro Approaches, Sage, Los Angeles.

Sorensen, E. E., Seebeck, E. D., Scherb, C. A., Specht, J. P., \& Loes, J. L. (2009), "The Relationship Between RN Job Satisfaction and Accountability", Western Journal of Nursing Research, Vol. 31, No. 7: 872-888.

Sökmen, A., Kenek, G., \& Ekmekçioğlu, E. B. (2017), “Etkileşimsel Adalet ve Duygusal Bağlılık iliş̧kisi: Algılanan Örgütsel Desteğin Düzenleyici Rolü”, İşletme Araştırmaları Dergisi, C. 9, S. 4: 196-214.

Specht, J. K. (1996), "The Effects of Perceived Nurse Shared Governance on Nurse Job Satisfaction and Patient Satisfaction", Doctoral dissertation, University of lowa, lowa City.

Stamper, C. L., \& Johlke, M. C. (2003), "The Impact of Perceived Organizational Support on the Relationship Between Boundary Spanner Role Stress and Work Outcomes", Journal of Management, Vol. 29, No. 4: 569-588.

Şen, C. \& Basım, H. N. (2018a), "Psikolojik Sermayenin Sinizm Üzerindeki Etkisi: Kültürel sıkılık-Esnekliğin Düzenleyici Rolü”, International Conference on Empirical Economics and Social Sciences (ICEESS'18), Bandırma-Türkiye: 317338. 


\section{Eskişehir Osmangazi Üniversitesi İktisadi ve İdari Bilimler Fakültesi Dergisi}

Şen, C. \& Basım, H. N. (2018b), "The impact of Psychologıcal Capital on Job Performance and Cynicism: The Moderator Effect of Cultural Tightness-Looseness", Social Sciences Studies Journal, Vol. 4, No. 19: 2402-2423.

Şen, C.; Okun, O. \& Arun, K. (2019), "Effectiveness in a Cultural Context: Paternalistic Leadership on Organizational Performance Within a Cultural Tightness and Looseness Model", 2. ERASMUS Uluslararası Akademik Araştırmalar Sempozyumu: 63-76.

Tabachnick, B. G. \& Fidell, L. S. (2013), “Using Multivariate Statistics”, 6th edition, Boston: Pearson.

Tang, Z., Chen, L., Zhou, Z., Warkentin, M., \& Gillenson, M. L. (2019), "The Effects of Social Media Use on Control of Corruption and Moderating Role of Cultural Tightness-Looseness". Government Information Quarterly, Vol. 36, No. 4: 101384.

Tetlock, P. E. (1983a), “Accountability and Complexity of Thought”, Journal of Personality and Social Psychology, Vol. 45: No. 1: 74-83.

Tetlock, P. E. (1983b), "Accountability and Perseverance of First Impressions”, Social Psychology Quarterly, Vol. 46, No. 4: 285-292.

Tetlock, P. E. (1985a), “Accountability: The Neglected Social Context of Judgment and Choice”, Research in Organizational Behavior, Vol. 7, No. 1: 297-332.

Tetlock, P. E. (1985b), “Accountability: A Social Check on the Fundamental Attribution Error", Social Psychology Quarterly, Vol. 48, No. 3: 227-236.

Tetlock, P. E. (1992), "The Impact of Accountability on Judgment and Choice: Toward a Social Contingency Model", Advances in Experimental Social Psychology, Vol. 25, No. 3: 331-376.

Tetlock, P. E., Vieider, F. M., Patil, S. V., \& Grant, A. M. (2013), “Accountability and ideology: When left looks right and right looks left", Organizational Behavior and Human Decision Processes, Vol. 122, No. 1: 22-35.

Thoms, P., Dose, J. J., \& Scott, K. S. (2002), "Relationships Between Accountability, Job Satisfaction, and Trust", Human Resource Development Quarterly, Vol. 13, No. 3: 307-323.

Turunç, Ö., \& Çelik, M. (2010), “Çalışanların Algıladıkları Örgütsel Destek ve İş Stresinin Örgütsel Özdeşleşme ve İ̧̧ Performansına Etkisi", Yönetim ve Ekonomi, C. 17, S. 2: 183-206.

Uzunbacak, Ö. Ü. H. H., Akçakanat, Ö. Ü. T., \& Çarıkçı, i̇. H. (2018), "Lider-Üye Etkileşimi ile Yenilikçi İş Davranışı Arasındaki İlişkide Algılanan Örgütsel Desteğin ve İşe Adanmışlığın Rolü”, 6. Örgütsel Davranış Kongresi Bildiriler Kitabı: 17-29.

Üstün, F., \& Kılıç, K. C. (2017), "Sıkılık-Esneklik Kültür Boyutunun Yönetsel ve Yapısal Çeşitli Değişkenlere Göre İncelenmesi: Türkiye'nin Öncü Sanayi İşletmeleri Üzerine Bir Araştırma", Gaziantep University Journal of Social Sciences, C. 16, S. 4: 963-979.

Van Dyne, L., Jehn, K. A., \& Cummings, A. (2002), "Differential Effects of strain on Two forms of Work Performance: Individual Employee Sales and Creativity", Journal of Organizational Behavior, Vol. 23, No. 1: 57-74.

Van Scotter, J. R., \& Motowidlo, S. J. (1996), "Interpersonal Facilitation and Job Dedication as Separate Facets of Contextual Performance", Journal of Applied Psychology, Vol. 81, No. 5: 525-531.

Wasti, A. S., \& Fiş, A. M. (2010), “Örgüt Kültüründe Sıkılık-Esneklik Boyutu ve Kurumsal Girişimciliğe Etkisi”, Yönetim Araştırmaları Dergisi, C. 10, S. 1-2: 11-33.

Wikhamn, W., \& Hall, A. T. (2014). Accountability and Satisfaction: Organizational Support as a Moderator. Journal of Managerial Psychology, Vol. 29, No. 5: $458-471$.

Witt, L. A., \& Carlson, D. S. (2006). The Work-Family Interface and Job Performance: Moderating Effects of Conscientiousness and Perceived Organizational Support. Journal of Occupational Health Psychology, 11(4), 343357.

Yarnold, P. R., Mueser, K. T., \& Lyons, J. S. (1988), "Type A behavior, Accountability, and Work Rate in Small Groups", Journal of Research in Personality, Vol. 22, No. 3: 353-360.

Yaşlığlu, M. M. (2017), "Sosyal Bilimlerde Faktör Analizi ve Geçerlilik: Keşfedici ve Doğrulayıcı Faktör Analizlerinin Kullanılması", İstanbul Üniversitesi İ̧̧letme Fakültesi Dergisi, C. 46, S. Özel sayı: 74-85.

Yetgin, M. A. (2016), “Örgütsel Psikolojik Sermaye ve Destekleyici Örgüt Kültürünün Otantik Liderlikte Rolü: Görgül Bir Arastırma, Üçüncü Sektör Sosyal Ekonomi, C. 51, S. 2: 128-156.

Zajonc, R. B. (1965), "Social Facilitation. Science”, Vol. 149, No. 3681: 269-274.

Zellars, K. L., Hochwarter, W. A., Lanivich, S. E., Perrewé, P. L., \& Ferris, G. R. (2011), “Accountability for Others, Perceived Resources, and Well Being: Convergent Restricted Non-Linear Results in Two Samples", Journal of Occupational and Organizational Psychology, Vol. 84, No. 1: 95-115. 


\section{Extended Summary}

\section{Moderation Roles of Perceived Organizational Support and Tightness of Organizations in Relationships between Felt Accountability and Its Consequences in Health Services: A Research in the City Hospital}

Although there is a widespread interest in the phenomenon of accountability in many areas of life, there has been no comprehensive psychological research about this concept (Lerner and Tetlock, 1999: 255). It has been determined that the psychological mechanisms examined at the individual level and stated as felt accountability are not taken into consedaration (Hall, 2005: 2). The aim of this research is to reveal the effects of felt accountability on various attitudes and behaviors of employees. The other aim of this study is to investigate the moderation roles of perceived organizational support and tightness of organizations in the relationships between felt accountability and its consequences that job satisfaction, job-related tension, contextual performance, emotional labor and the dimensions of emotional labor which are deep actions, histrionics, hidden emotions). The main questions of this research are: Does the tightness of organizations have a moderation effect on the relationships between felt accountability and its consequences?; Does the perceived organizational support have a moderation effect on the relationships between felt accountability and its consequences?

Felt accountability refers to "an implicit or explicit expectation that one's decisions or actions will be subject to evaluation by some salient audience(s) (including self) with the belief that there exists the potential for one to receive either rewards or sanctions based on this expected evaluation" (Hall, 2005: 21). When the literature is examined, it is found that while some researchers found (Specht, 1996; Thoms et al., 2002, Sorensen et al., 2009; Breaux et al., 2008; Breaux et al., 2009; Laird et al., 2009; Laird et al., 2015; Royle, 2017) a positive correlation between felt accountability and job satisfaction; the other researchers (Hall et al., 2006; Lanivich et al., 2010) concluded that accountability and job satisfaction are negatively related. Some researchers' results (Ferris et al.,1995; Hall et al., 2003; Hochwarter et al., 2005; Hall et al., 2006; Hochwarter et al., 2007; Breaux et al., 2008; Laird, et al., 2009; Zellars et al., 2011) indicated that felt accountability and work-related tension is positively correlated. Similarly, it was observed that the results of Hall et al. (2003) showed a positive relationship between felt accountability and emotional labor and Chen et al. (2016) obtained that felt accountability and contextual performance are a positively related. Although some studies have looked at the moderation effect of tightness (Altuncu, 2014; Lönnqvist, 2015; Şen and Basım, 2018a; Şen and Basım, 2018b; Liu et al., 2018; Tang et al., 2019; Şen et al., 2019) there is no study examining the effect of tightness of organizations as a moderation variable in the relationships between felt accountability and its consequences in the literature. It was seen that some researhers (Lynch et al., 1999; Stamper and Johlke, 2003; Erdogan et al. , 2004; Witt and Carlson, 2006; Erdogan and Enders, 2007; Nixon et al., 2011; Gopalkrishnan, 2011; Conway and Coyle-Shapiro, 2012; Hur et al., 2015; Fettahlığlu \& Koca, 2015; Palmer et al., 2017; Sökmen et al., 2017; Chung, 2017; Cheng and O-Yang, 2018; Uzunbacak et al., 2018; Işık, 2019; Acaray, 2019; Koçak, 2020) examined the perceived organizational support as a moderator variable but they did not investigate felt accountability in their studies. Only Wikhamn and Hall (2014) found that there was moderation role of perceived organizational support between felt accountability and job satisfaction.

The data is obtained with the convenience and snowball sampling methods via survey from 863 employees working in Adana City Hospital. Research model have seven variables. Felt accountability is independent variable while job satisfaction, job-related tension, contextual performance and emotional labor are dependent variables. Tightness of organization and perceived organizational support are moderator variables. In this research, normality analysis, reliability analysis, exploratory factor analysis, multicollinearity analysis, corelation analysis were performed with SPSS 18.00 program. On the other hand, confirmatory factor analysis and the hypotheses were tested with AMOS 23.00 program.

As a result, felt accountability was positively associated with job-related tension, the dimensions of emotional labor and contextual performance, but negatively correlated with job satisfaction. Moreover, perceived organizational support had a moderation role between felt accountability and some consequences (job satisfaction, contextual performance, histrionics), whereas it had no moderation role between felt accountability and the other consequences (work-related tension, deep action, hidden emotions). Similarly, there was no moderation effects of the tightness in the relationship between felt accountability and its all consequences. The results we obtained in the study are consistent with the literature. This study provides information about consequences and moderators of felt accountability. Based on research findings, felt accountability has an impact on a variety of work attitudes and the results regarding the moderation variables of felt accountability contributed to the literature. Our current research makes a significant contribution to the meso-level accountability literature by integrating the individual (internal) and organizational (external) factors in the proposed model. 